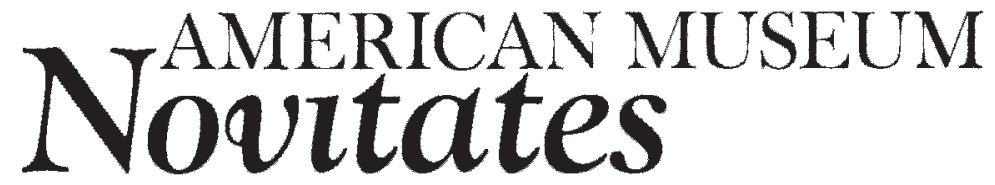

PUBLISHED BY THE AMERICAN MUSEUM OF NATURAL HISTORY CENTRAL PARK WEST AT 79TH STREET, NEW YORK, NY 10024 Number 3679, 26 pp., 73 figures, 1 table

March 4, 2010

\title{
Biology and Morphology of the Immature Stages of the Cleptoparasitic Bee Coelioxys chichimeca (Hymenoptera: Apoidea: Megachilidae)
}

\author{
JEROME G. ROZEN, JR., ${ }^{1}$ S. BRADLEIGH VINSON, ${ }^{2}$ ROLLIN COVILLE ${ }^{3}$ AND \\ GORDON FRANKIE ${ }^{4}$
}

\begin{abstract}
Herein we investigate the behavior and anatomy of all larval instars of the cleptoparasitic bee, Coelioxys (Cyrtocoelioxys) chichimeca Cresson. The species is found in Central America with its host, Centris (Heterocentris) bicornuta Mocsáry, one of the cavity-nesting members of the genus. The egg/mature oocyte of C. chichimeca, unusually small (like known eggs of other Coelioxys), is described, as is egg placement in the wall of the brood chamber. The anatomy and behavior of each of the five larval instars is described. The first instar develops within the egg chorion, from which the second instar emerges. The second and third instars apparently normally remain attached by their posterior ends either to the egg chorion or to the place where the egg had been attached to the cell wall. The second instar possesses an array of large spines on the outer surface of each mandible thought to rupture the thick chorion, thus allowing eclosion. Both second and third instars have modified head capsules and mandibles enabling them to attack host immatures. Both instars possess an extremely large pair of spiracles on the eighth abdominal segment and lesser-enlarged spiracles on the two preceding abdominal segments as well as enlarged internal lateral tracheal trunks. These modifications are likely related to the need for the larva to acquire air from the substrate while the body is submerged in nectar. Fourth and fifth instars, no longer attached to the substrate, assume the morphological attributes and behavior of normal provisions-consuming megachilid larvae. The last larval instar defecates and afterwards spins a cocoon bearing a conspicuous nipple. A male pupa is also illustrated and described.
\end{abstract}

\footnotetext{
${ }^{1}$ Division of Invertebrate Zoology, American Museum of Natural History (rozen@amnh.org).

${ }^{2}$ Department of Entomology, Texas A\&M University, College Station, TX 77843 (bvinson@ag.tamu.edu).

${ }^{3} 6201$ Tehama Ave., Richmond, CA 94804 (rollincoville@pacbell.net).

${ }^{4}$ Department of Environmental Science, Policy, and Management, College of Natural Resources, University of California, Berkeley, CA 94720 (frankie@nature.berkeley.edu).
} 


\section{INTRODUCTION}

Baker's (1971) detailed study of Coelioxys has stimulated a number of recent investigations of that genus (Carré and Py, 1981; Rozen and Kamel, 2006, 2007, 2008) as well as of the related cleptoparasitic megachiline genus Radoszkowskiana. These studies, though restricted to only a few species, have documented that within this large genus of more than 480 species, cleptoparasitic behavior and related immature anatomy varies extensively. Vinson et al. (in press) present information on adult behavior of Coelioxys (Cyrtocoelioxys) chichimeca Cresson, which is known from southern Mexico to Panama (Discoverlife. org). In the current investigation we examine the same species, in this case exploring larval behavior and associated morphology and providing comparative descriptions of all immature stages. Females of $C$. chichimeca attack nests of Centris (Heterocentris) bicornuta Mocsáry, an abundant, cavity-nesting bee in Guanacaste Province, Costa Rica. They may also attack nests of other cavity-nesting species of Centris in the same area.

This investigation was carried out at Hacienda Monteverde, a ranch owned by D.A.S. Stewart, $8 \mathrm{~km}$ north-northwest of Bagaces (centered at $\mathrm{N} 10^{\circ} 34.110^{\prime} \mathrm{W} 85^{\circ}$ $18.419^{\prime}$ ), a locality used by Frankie and colleagues for several years to investigate the bee fauna of Costa Rica. This area is a lowland forest (elevation at trap-nest sites $360-370 \mathrm{ft}$ ) on the dry side of the mountains, dominated in undisturbed areas by low to tall trees (maximum height $25 \mathrm{~m}$ ). The three trapnest sites (figs. 1-3) for the study were along the edge of a forested area $\left(\mathrm{N}_{10} 35.506^{\prime}\right.$ W8 $5^{\circ} 18.280^{\prime}$ ) with a large open agricultural field immediately to the south. Although J.G.R.'s participation in the field study in Costa Rica extended from February 10-24, 2009, S.B. and G.F. had conducted an extensive trap-nesting study in the late 1990s and early 2000s in the area surrounding the main study site referred to in this paper. In addition to a wealth of year-round information on the bees and wasps that use stick traps, the study also provided insight on the locations for the greatest diversity of bee species and their associates (Frankie and Vinson, in prep.).

\section{METHODS AND TERMINOLOGY}

All nests of Centris bicornuta examined were in artificial trap nests. Each trap nest was composed of a group of 10 individual pieces of wood, $4^{\prime \prime} \times 1^{\prime \prime} \times 3 / 4^{\prime \prime}\left["=\right.$ inches; $\left.1^{\prime \prime}=2.5 \mathrm{~cm}\right]$, into one end of each had been drilled a $3^{\prime \prime}$ deep hole, which constituted the preformed cavity in which bees nested. Bore diameters varied as follows: 3/16", 1/4", 5/16", and 3/8". Each bundle of 10 pieces of wood was taped together with alternate pieces facing opposite directions (fig. 4), so that each trap nest consisted of two stacks of five sticks. A double stack (i.e., trap nest) held two boreholes of each diameter except it held four with 1/4" boreholes. Casual observations indicated that Centris bicornuta nested primarily in the $1 / 4^{\prime \prime}$ and $5 / 16^{\prime \prime}$ boreholes rather than in the $3 / 16^{\prime \prime}$ and $3 / 8^{\prime \prime}$ holes. Each taped trap nest was provided with a string so that it could be suspended from a nail driven into a tree trunk or branch. The intent was to have the boreholes approximately horizontal. Groups of approximately 10 trap nests were hung on one or several adjacent trees in three separate but adjacent areas of Hacienda Monteverde (figs. 1-3) at approximate eye level to be monitored for nesting activity. At one- or two-week intervals trap nests were collected, either to be held in the field lab ${ }^{5}$ so that adults could be reared or to be split open in the field lab for analyses and collection of immatures (fig. 7). Simultaneously with the collection of trap nests, we replaced them with fresh ones. When emerging adults were to be collected, trap nests were disassembled in the lab, sticks were individually labeled for locality and time of collection, and a vial was taped to each opening to receive emerged adults (fig. 6).

Observations in Costa Rica were made with a Leitz stereomicroscope and recorded with a Cannon PowerShot SD880 IS camera held to the ocular lens of the stereoscope.

Immatures in the American Museum of Natural History lab were always examined first with a stereoscope. If they were to be cleared for study, larvae with heads partly severed from bodies were boiled in an aqueous

\footnotetext{
${ }^{5}$ The hotel where the authors stayed while in Costa Rica kindly provided space for dissecting and examining trap nests and for storing specimens and equipment.
} 

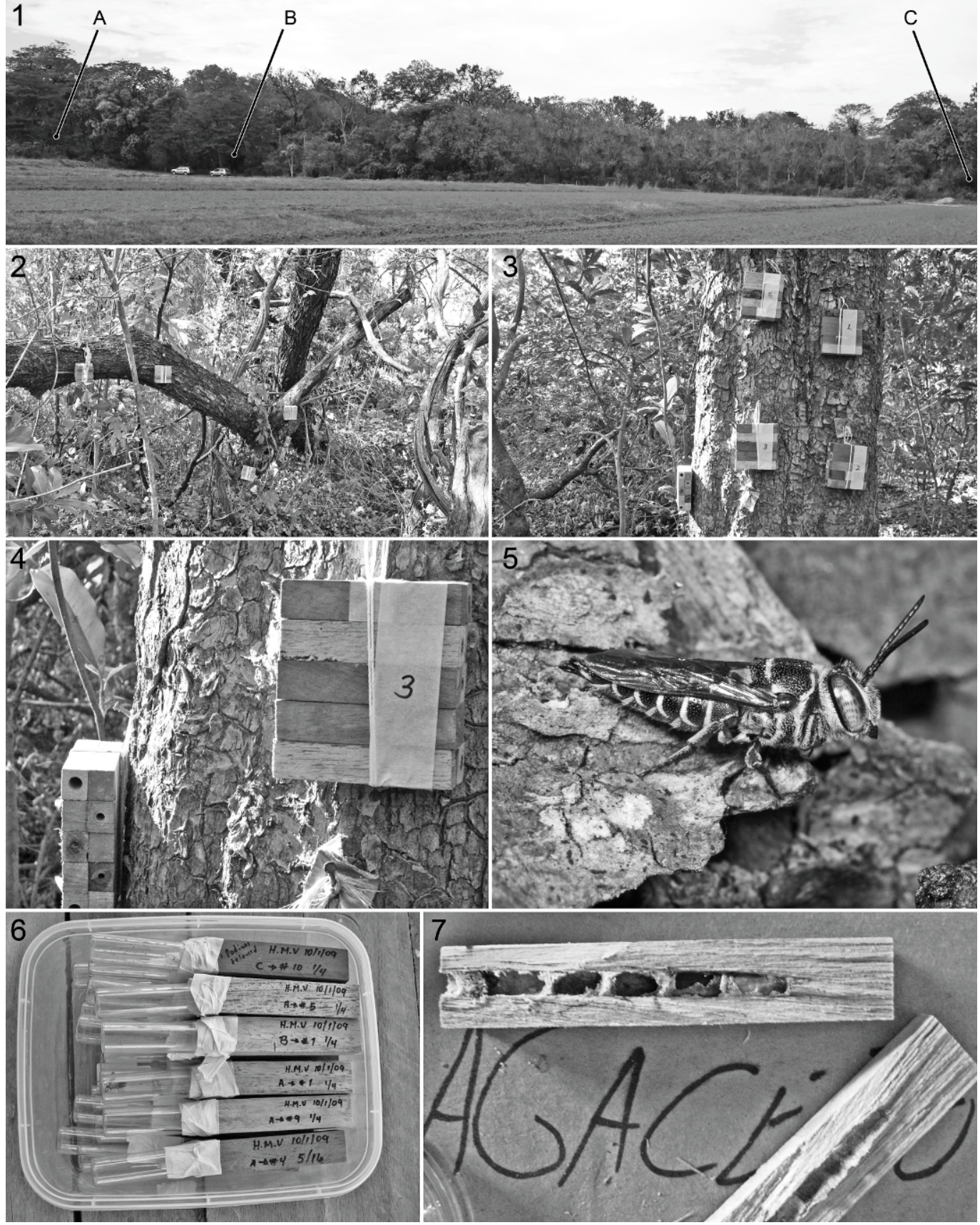

Figs. 1-7. Photographs of trap nests and the trap-nesting sites at Hacienda Monteverde, where Centris bicornuta was induced to nest. 1. Approximate position of three sites (A, B, C) in the forest along the northern edge of a large agricultural area. 2, 3. Trap nests hung from nails driven into trees and branches at sites A and C, respectively. 4. Close-up of one trap nest consisting of 10 individual sticks. 5. Female perched outside nest waiting for host female to enter or leave (photo courtesy of Rollin Coville). 6. Individual sticks being held to retrieve emerging adults of host and cleptoparasites. 7. An individual nest stick opened to reveal nest structure and immatures. 
solution of sodium hydroxide until cleared. After staining with Chlorazol Black $\mathrm{E}$ in ethanol, they were transferred to glycerinfilled well slides for detailed examination with stereoscope and/or compound microscope. Numerous cast exoskeletons attached to larvae were also a source of valuable information concerning the anatomy of the different instars and early on solved the puzzle of the sequence of instars.

Some immatures were examined with a Hitachi S-5700 scanning electron microscope (SEM) after they were critical-point dried and coated with a gold/palladium alloy.

We introduce here a new statistic, cranial swelling index. With many cleptoparasitic bees there is a tendency for the cranium to become enlarged in the hospicidal instar, often in association with thickening and resulting darkening plus sclerotization of the parietal cuticle. Rozen (1991) postulated that this is probably due to the strengthening and enlarging of parietals required for operation of extra adductor musculature involved with the large, forceful mandibles required for killing host immature or immatures of competing cleptoparasites. The index is determined by dividing the maximum horizontal width of the foramen magnum by the maximum horizontal width of the head capsule. Thus, the lower the index value, the greater the swelling. However, in the case of third instar Coelioxys chichimeca the low value of the index is probably also partly explained by the head capsule being wide, thus enhancing the chance of widely opened mandibles (fig. 18) encountering and grasping victims in a totally dark environment. Note that the widest part of the head capsule is at the bases of the mandibles.

Rozen (1991) has also hypothesized that muscle strength in some cleptoparasitic larvae is increased by lengthening of the head capsule rather than by its swelling since both modifications add more space for the attachments of massive musculature. There is also a tendency among hospicidal instars, whether with enlarged, globose heads or elongate ones, to have the labiomaxillary regions of the head more extensively sclerotized than those of related solitary bees, often in association with development of a ventral postoccipital bridge. These modifications add rigidity to head

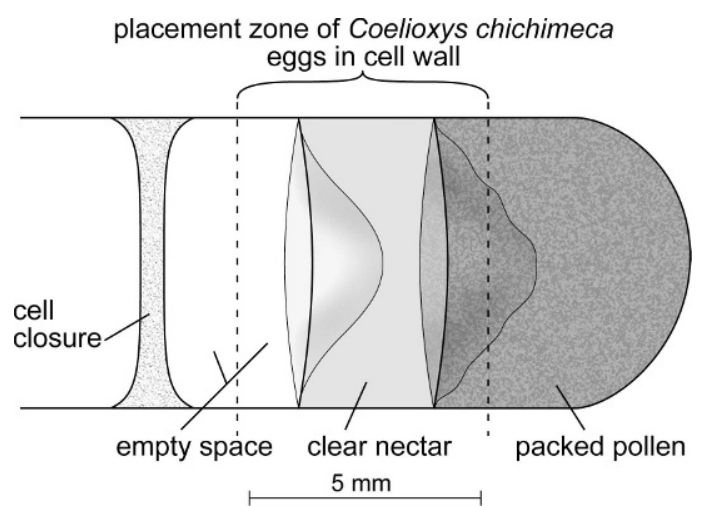

Fig. 8. Diagram of a cell of Centris cornuta, cross-section, side view, identifying the zone in which eggs of the cleptoparasite, Coelioxys chichimeca, have been found embedded in the cell wall, in relation to the distribution of stored provisions.

capsules, thereby enhancing mandibular strength and attacking dexterity.

In describing mandibular shape we use the term fanglike: long, curved, tapering to a single sharp point, sometimes with a more extreme curvature near the apex (fig. 45).

In the biology section, we use the terms cell wall and cell lining in regard to brood chambers of Centris bicornuta. With this species, the cell wall is simply the bore of the trap nest, the material that closes the borehole at the rear of the chamber, and the thin, transparent to semitransparent coating that covers the inner surface of the cell. The cell lining is that thin, transparent coating. It is thought to be waterproof and a barrier to gas exchange.

In the figures, we use the following abbreviations: $\mathrm{PTP}=$ posterior tentorial pit. $\mathrm{T}=$ metasomal tergum (e.g., T6 = sixth metasomal tergum). $\mathrm{S}=$ metasomal sternum (e.g., $\mathrm{S} 6$ $=$ sixth metasomal sternum).

\section{BIOLOGY}

All information on the nesting biology of Centris bicornuta and the cleptoparasite, Coelioxys chichimeca, came from three trapnest sites (fig. 1). A fully provisioned nest cell of this host species, diagramed in figure 8, contains a layer of opaque, densely packed pollen that the female host bee first loads into the rear one-third of the cell. The front face of 
the pollen is deeply concave. The host then deposits a similar quantity of clear nectar (Vinson et al. 2006) against the pollen surface to which it adheres because of its sticky, thick consistency. The nectar's surface is also concave, more or less conforming to the concavity in the pollen. The cell wall in front of the surface is barren except for the cell lining; the nectar does not extend foreword to the cell closure. Thus the front end of the cell is empty; a "dry" area remains on the sides, top, and bottom of the cell wall between the cell closure and the voluminous nectar and pollen provisions. Figure 8 identifies the zone where we have detected the egg insertion pits of $C$. chichimeca in the dry area of the cell wall in front of the provisions, as well as in the cell wall under the clear nectar area, and also under the densely packed pollen. Vinson et al. (submitted) noted that most of these egg insertion pits were placed in the upper $3 / 4$ of a cell, but the distance from the cell cap was not determined.

Oviposition: The distance between floral resources and the trap-nest sites was not determined, but abundance of host females at the trap nests demonstrated that resources were clearly nearby in the form of flowering trees. Coelioxys chichimeca visits to the three trap-nest sites were moderately frequent but mostly single events in that usually only one parasitic female was seen at a time. She would suddenly appear at one trap nest, swiftly circle around it, then swoop to the next trap nest, and on to other nests, until she discovered an appropriate one. When a female cleptoparasite detected an opening of interest, she hovered briefly in front of the entrance, and occasionally she alighted and entered headfirst. On emerging she either departed or reversed her direction at the entrance and reentered backward. Emerging again shortly afterward, she would fly away. We interpret the backward entrance of the female as an indication that she was about to oviposit in the cell. Occasionally, we observed a female of C. chichimeca with raised antennae perching outside an entrance presumably waiting for evidence of a host female's departure or return (fig. 5). Such behavior might continue for some minutes, often with the cleptoparasite taking short flights to reposition herself around the entrance. These summary observations have been described and documented by Vinson et al. (submitted).

We observed eight or nine cleptoparasitic oviposition sites with eggs in place, all partially buried lengthwise. In each case the long axis of an egg was more or less parallel to the inner cell surface. All had been inserted far enough to reach the substrate beyond the cell lining (fig. 14), possibly a significant requirement for obtaining air, as discussed below. Egg insertion sites were either where the pollen-covered surface was shallow (fig. 8) or in the nectar area (fig. 8) in front of the pollen surface. A few eggs were not covered even by clear nectar (i.e., inserted in the dry area of the cell wall) and others were shallowly covered, but in some cases the nectar covering may have resulted accidentally during our transporting the trap nests to the field laboratory. In all cases the egg was positioned in the excavation with the broad anterior end facing the cell closure and the narrow posterior end inserted in the opposite direction and buried more deeply than the anterior end; hence, eggs were inserted slightly obliquely (i.e., "toenailed") into the cell wall. Excavations were elongate ovals, just sufficiently large to accommodate the egg (i.e., about $1 \mathrm{~mm}$ long) and presumably made by the female at the time of oviposition, probably with the elongate, sharply pointed median process of metasomal sternum 6. Depth of excavation relative to the cell's inner surface varied from shallow (so that the exposed surface of the egg projected above the cell surface; fig. 10) to deep (exposed egg surface well below the cell surface). Mature oocytes/eggs are described in Ovarian Statistics and Descriptions of Immatures, below.

In addition to these successfully inserted eggs, we observed a number of elongate-oval insertion pits that in a few cases showed remnants of vacated egg chorions (presumably evidence of successful insertions) (fig. 13), which are sufficiently thick that they do not seem to dissolve as do chorions of nonparasitic, solitary bees, or, more frequently, exhibited insertion pits without vacated chorions (fig. 14). Such pits were encountered in cells without other evidence of cleptoparasitism as well as in cells with another pit holding 

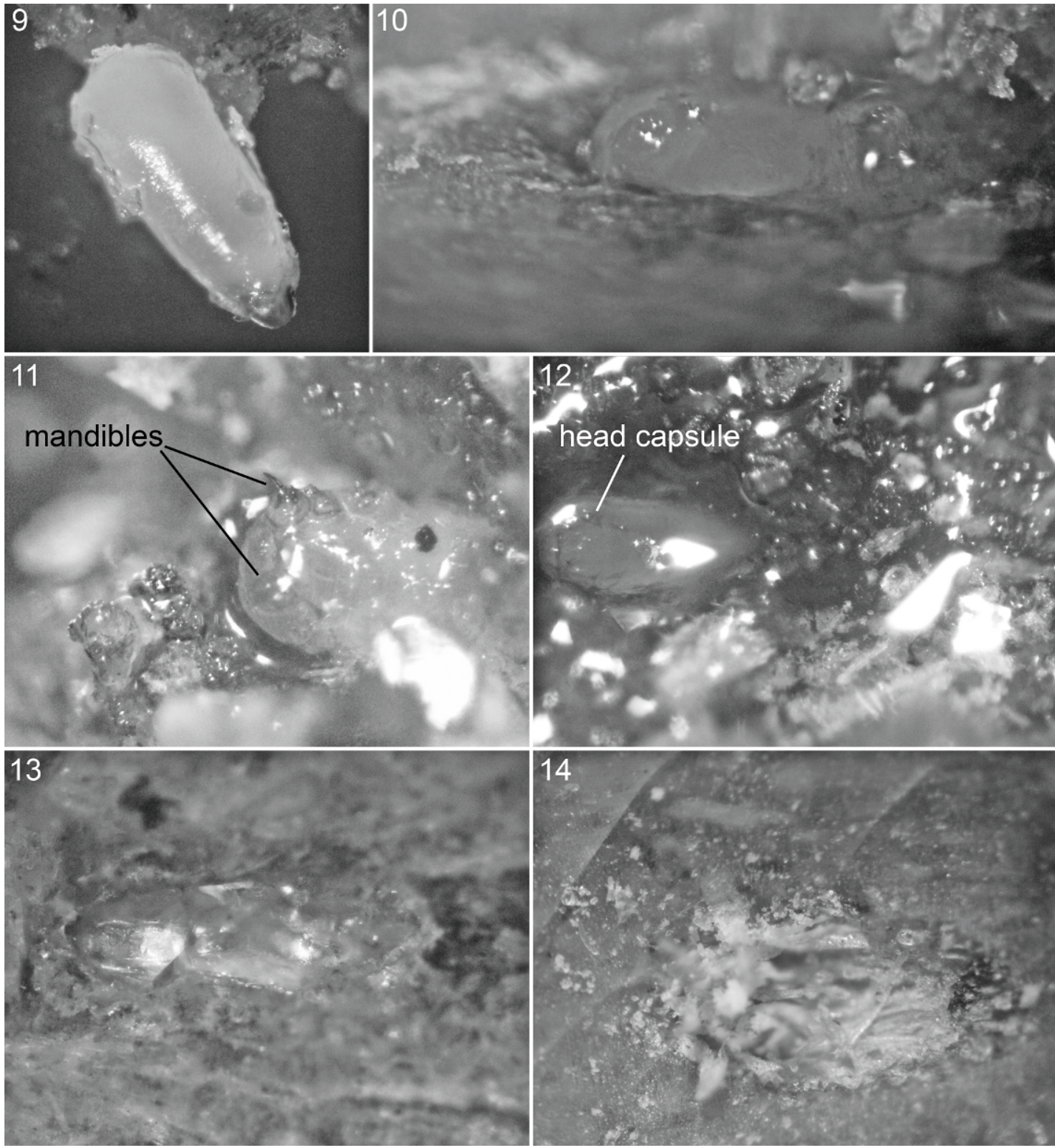

Figs. 9-14. Microphotographs of egg and egg insertions of Coelioxys chichimeca in cells of Centris cornuta. 9. Individual egg extracted from cell wall. 10. Egg in shallow pit. 11. Eclosing second instar with head emerged from chorion. 12. Egg with dark mandibles and parietals of second instar visible. 13. Egg insertion pit where only chorion of cleptoparasite remains. 14. Egg insertion pit lacking evidence of egg.

an egg. An insertion pit without even a vacated chorion may represent an incomplete act of egg deposition, perhaps occasioned by sudden return of the host female, but it may also be evidence (1) that a second female Coelioxys chichimeca encountered a cell that had already been attacked and removed the first egg or (2) that a returning Centris bicornuta female destroyed an offending parasite egg.

Although discovered oviposition sites were in cell walls where there was either no pollen 

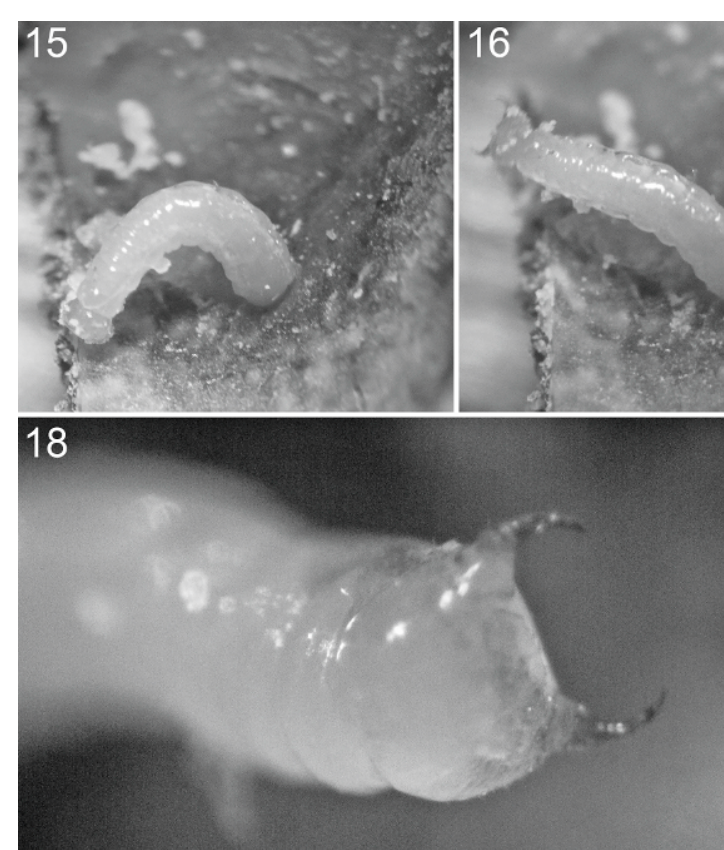
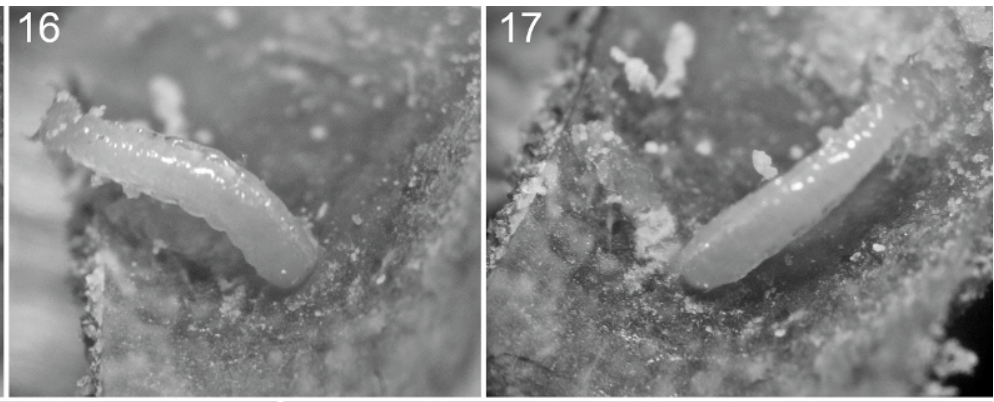

19

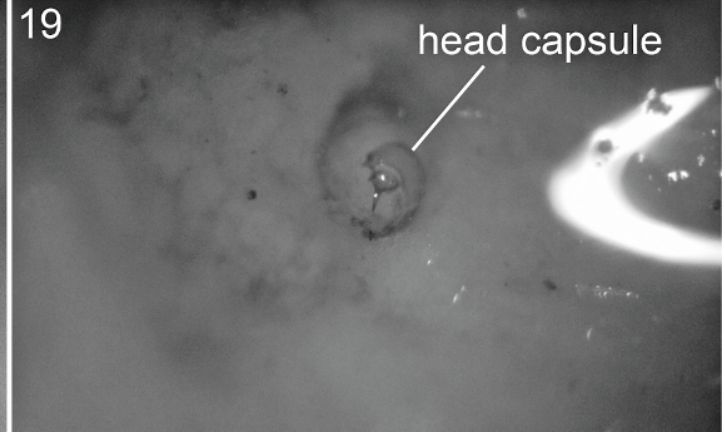

Figs. 15-19. Photomicrographs of Coelioxys chichimeca. 15-17. Three frames of single third instar demonstrating reach of activity while posterior end attached to egg chorion imbedded in cell wall. 18. Closeup of head of another third instar showing spread of mandibles enabling it to seize victim immediately on contact. 19. Second instar immersed in nectar while posterior end attached to chorion inserted in cell wall under pollen layer of provisions.

or only a shallow layer, we also discovered several second instars (sometimes with only their heads visible through the nectar extending from a hole in deeper pollen, figs. 8, 19), an indication that eggs are sometimes also deposited farther back toward the rear of cells. Such submerged larvae raise the interesting question of how these active larvae acquire oxygen, a subject discussed below.

LARVAL INSTARS AND THEIR BEHAVIOR: Like other Coelioxys species that have been studied in detail, $C$. chichimeca has five larval instars (Baker, 1971; Rozen and Kamel, 2006). The first instar (fig. 32) is known only from cast exuviae in a single egg chorion still attached to the rear part of the abdomen of a second instar that had been preserved. The cast skin was discovered appressed to the inner surface of the chorion near the rear end of the egg. As indicated in the description, below, it is without pigment and weakly sclerotized. Its tracheal system and internal head ridges cannot be identified. Only a pair of mandibles is visible, except laterad of each is a small, sharply defined tubercle of questionable homology. Whatever the instar's adaptive functions, it represents a life stage that obviously is necessary for development of the second instar with its distinctive, darkly pigmented head capsule and mandibles, i.e., the stage that hatches from the egg.

Eclosion, i.e., the hatching of the larva from the egg, occurs as the second instar slowly emerges, leaving first-instar exuviae behind in the chorion, as evidenced in figure 32. We were able to monitor eclosion of the second instar in detail on one occasion, and we also observed the early stages of eclosion in two other cases. During the monitored eclosion we looked through the chorion to see the opening-and-closing movement of the mandibles and their developing pigmentation. We think it highly likely that the mandibular motion causes the array of sharp-pointed, diverging basal mandibular tubercles as well as the more apical tubercle on the outer mandibular surface to rupture the chorion, thus allowing the larva to emerge. In both instances of 
observed eclosion, the second instar had its ventral surface facing the exposed chorion (fig. 11), so that its dorsal surface was buried against the cell wall. In one instance, the opening-and-closing mandibles were detected around 9 P.M. and by the following morning, the larva had partly emerged from a large circular hole near the anterior end of the chorion (fig. 11); the rear part of the body was still clearly contained in the posterior end of the chorion. Thus the larva was bent Ushaped, so that its anterior part pointed toward the rear of the chorion. When touched with forceps, the anterior end immediately rose up with mandibles opening and closing in an aggressive display so that the anterior end was at right angles to the cell wall. The erection of the anterior part of the body and gnashing of mandibles was accompanied by searching gyrations of the anterior body region, a behavioral pattern that J.G.R. has seen with third larval instars of other Coelioxys species. This behavior indicates that the second instar of this species is equipped to fight other cell inhabitants, a conclusion supported by the strongly sclerotized and pigmented mandibles and head capsule, by the aggressive behavior of the second instar observed in a number of cases, and by dead host immatures in cells with second instars of Coelioxys.

The second instar whose eclosion we monitored remained attached to the egg insertion point all of the second day, feeding on the nectar that coated the surroundings of the egg deposition site, so that the larva grew in size. During the second night, it molted to the third instar and was preserved the following morning.

We think it likely that second and third instars (the latter often with cast skins of the previous instar clinging to their bodies) are normally attached by their posterior ends to the chorions embedded in the cell walls. Although some free-ranging young instars were also sighted, attachment of a small larva to the egg placement was a significant and noteworthy phenomenon. Baker (1971) reported this phenomenon for $C$. (Boreocoelioxys) octodentata Say and $C$. (Boreocoelioxys) sayi Robertson, as apparently did Iwata (1939) (fide Baker, 1971; in
Japanese, not read by current authors) for $C$. (Coelioxys) elongata Lepeletier. The bodies of the larger second and third instars of $C$. chichimeca (figs. 33, 38, 41) appear unusually elongate (more so than comparable instars of C. bicornuta) suggesting that elongate body form was involved with their attachment to their natal origins. We found a few second instars submerged in nectar in thicker layers of pollen (fig. 19), but in hindsight, after examining photographs, we had apparently overlooked that attachment in some of the third instars because their posterior ends where obscured in provision. When one sees a larva attached to a relatively dry surface (e.g., figs. 15-17), it is clear such seemingly gravity-defying acrobatics requires that the larva be attached by it posterior end.

We think that such attachments may serve two needs: (1) to obtain air in cases in which the small cleptoparasitic larva is submerged under nectar (fig. 19), and (2) to provide a stable fixed surface so the hospicidal larva can successfully attack the host immature on or in a surface covered by nectar. We explain these two hypotheses as follows:

(1) The need for air relates to observations that at least some eggs of $C$. chichimeca are attached to the substrate where they are submerged below the nectar surface or even further into the pollen provisions. The fact that the posterior ends of the second and third instars have greatly enlarged spiracles (see Ovarian Statistics and Descriptions of Immatures, below) suggests that larvae obtain air by use of enlarged spiracles. Although this discovery at first seemed counterintuitive because the posterior ends of these larvae are submerged deeper into the nectar than the anterior ends, we think that sufficient air to supply the larva comes from or through the substrate even if it is only wood. This hypothesis proposes that the egg deposition pits, penetrating through the presumably airtight cell lining to the wood fibers below, are the source of air for the larvae until they can rely upon air in the brood cell. This connection would also permit larger larvae to submerge while they feed beneath the liquid surface. This hypothesis is supported by the fact 
that all spiracles in the fourth and fifth instars, which are no longer attached to the substrate, are subequal in size (i.e., the norm for bee larvae). Questions that require further study include, How do enlarged spiracles of second and third instars connect to air supplied by the substrate? what role (if any) does egg chorion play in the transfer of air to the spiracles? and what mechanisms enable the larva to remain attached to the egg insertion point (although we wonder whether the unusually small 10th abdominal segment might remain in the egg chorion and thus anchor the larva)?

(2) Attacks on host immatures are often preceded by strong, gyrating, searching movements of the sometimes elevated, anterior part of the larva's body (fig. 1517) or by the nearly motionless, elevated anterior part of the body while mandibles are widely opened (fig. 18). Mandibles are rapidly closed when the larva encounters the host (or is teased with a probe). Second and third instar bodies are slender and agile and can rapidly twist and bend to subdue host immatures. The body actions are enhanced if the cleptoparasite has a firm point of contact with a stable substrate (i.e., egg insertion point) since the entire muscular force of the larva's body can be directed toward the host. Without a fixed point, the body would be unable to muster the same strength because the immediate environment (nectar) is fluid and therefore too yielding. The elongate length of the larva anchored only by its posterior end permits the larva with mandibles widespread to extend the search area for the host (figs. 15-17).

It seems unlikely that attachment of the posterior ends of second and third instars to their eggs is a special adaptation to overcome the thick layer of nectar on the surface of the provisions because of the identical attachments reported for other species where hosts do not cover the provisions with a separate layer of nectar (Baker, 1971; Iwata, 1939). We note that many Megachilidae have early instars that remain sessile on egg insertion points; might the behavior in Coelioxys be merely an expression of the sessile behavior expressed by other early instars in the family?

This leaves unexplained the free-roving small larvae of Coelioxys chichimeca that we occasionally saw. These may be individuals that have already destroyed the host or perhaps had been accidentally dislodged by our manipulations.

The two final instars did not appear to be attached in any way to their chorions but simply fed on the provisions, as do larvae of the host species.

The observations reported above only partly answer the requirements for successful oviposition and eclosion of $C$. chichimeca. We have observed some eggs inserted in the cell wall where there is no pollen or nectar that a second instar could ingest if it hatches, and we have also seen that second instars feed and grow as they gradually emerge from their chorions surrounded and covered by a thin layer of provisions. Does this mean that those eggs removed from larval resources will not survive? We have seen none do so, but data are scant.

Although position of the apical tubercle on the outer apical surface of the mandible suggests that it may be instrumental in rupturing the chorion, future investigations should consider the possibility that it might also function to limit the penetration of the mandibular apex deep into the host, thus preventing entanglement of the mandible with the host. This possibility should also be considered for the smaller, but now more apical, basal mandibular tubercles of the third instar (fig. 45).

In summary, our observations, supported by larval anatomy, indicate that the first instar remains in the chorion and has no direct contact with the environment in the cell. The second instar is the one that ecloses, has special anatomical modifications (spines on the outer mandibular surface) to do so, and, during and after eclosing, can and often does kill (with strongly curved, sharply pointed mandibles) the host egg or young larva. The third instar has reduced mandibular spines (the subapical one completely lost) and has even longer and more apically curved mandibles than before (fig. 45), so that it is equipped morphologically and behaviorally to kill the host larva and/or larvae of other cleptoparasites. Both second and third instars feed on 
provisions as evidenced by their increase in body size within and between stadia. We have insufficient data to estimate which of these two instars is more successful at eliminating the immature host. Fourth and fifth instars are probably the main feeding instars and, in addition, the fifth instar defecates (but we are uncertain whether defecation commences soon after the start of the stadium or only after food is totally consumed). After provisions are consumed and defecation is finished, the last larval instar spins its cocoon, as evidenced by the presence of fecal pellets only on the outside of the cocoon.

The single pupa, a male, recovered from a cell was found in a thin-walled, almost transparent cocoon that conforms to the inner shape of the cell. Its front end was faintly convex (conforming to the cell closure), bearing a central, dark brownish-red, opaque nipple of fibrous silk (i.e, the "disc" of Rozen and Kamel, 2007). Pale, elongate fecal pellets, mostly less than four times their maximum diameters, were loosely attached to the outer surface of the cocoon except for its front (cell closure) end. The pupa is described below.

\section{OVARIAN STATISTICS AND DESCRIPTIONS OF IMMATURES}

We obtained all specimens described here between February 10 and 24, 2009. Identification of larval instars was simplified because the cast exoskeleton of previous instars (though not the first) often remained on the sides or undersurface of the live specimen. Not uncommonly, we encountered fourth instars attached to which were skins including head capsules of the previous two instars. Table 1 compares the diagnostic features of the larval instars.

Descriptions of larval instars 2-4 are comparative to explore changes in anatomy that take place. Description of the last instar addresses the same anatomical features but also incorporates structures that have been referred to in accounts of other larval Coelioxys (e.g., Baker, 1971; Rozen and Kamel, 2007).

\section{Ovarian Statistics}

Two females of Coelioxys chichimeca each had three ovarioles per ovary, the basic number for all bee families except the Apidae. On average each female carried eight mature oocytes or 1.33 mature oocytes per ovariole. These are high numbers for noncleptoparasitic bees but within the range for cleptoparasitic ones including other species of Coelioxys (Rozen, 2003; Rozen and Kamel, 2007). Rozen (2003) explored the possible reasons for cleptoparasites having so many mature oocytes. The egg index (i.e., the length of the largest mature oocytes, divided by the distance between the outer rims of the tegulae, a statistic developed by Iwata and Sakagami, 1966) of Coelioxys chichimeca averaged 0.33 for the two females. This value places this species in the dwarf category (Iwata and Sakagami, 1966: table 2), with other members of the genus, all of which are either $d w a r f$ or at least small, as is characteristic of most cleptoparasitic bees (Rozen, 2003).

\section{Description of EgG/Mature Oocyte}

Figures 9, 20-23

Diagnosis: The egg/mature oocyte of Coelioxys chichimeca can easily be distinguished from those of other Coelioxys and of Radoszkowskiana by the ridge that extends lengthwise around it (figs. 20, 21, 23); this feature has not been reported before for other congeneric species (Graenicher, 1905; Iwata, 1939, 1955, 1965; Baker, 1971; Rozen, 2003; Rozen and Kamel, 2007). Shortness compared with its maximum width and its tapering shape in dorsal or ventral views are also unusual, though perhaps more difficult to compare with similar features in other taxa. Nonetheless, the micropyles of all that have been studied with an SEM are similar (fig. 22; Rozen, 2003: figs. 60, 61; Rozen and Kamel, 2007: fig. 33)

DeSCRIPTION: Length approximately $1.0 \mathrm{~mm}$; approximate maximum width $0.4 \times 0.45 \mathrm{~mm}$ (two dimensions because eggs/mature oocytes are slightly flattened), which is close behind the anterior end. Shape slightly curved with ventral surface concave in lateral view; anterior end broadly rounded in dorsal/ventral views; maximum breadth near anterior end, tapering evenly posteriorly toward narrowly round posterior end in both lateral and dorsal views 
TABLE 1

Major Characteristics of Five Larval Instars of Coelioxys chichimeca

\begin{tabular}{|c|c|c|c|c|c|}
\hline Character & First & Second & Third & Fourth & Fifth \\
\hline $\begin{array}{l}\text { Parietal } \\
\quad \text { pigmentation }\end{array}$ & Absent & \multicolumn{4}{|c|}{ Parietal } \\
\hline Parietal extension & $?$ & None & $\begin{array}{l}\text { Sclerotization } \\
\text { posterior to } \\
\text { postoccipital ridge } \\
\text { (fig. 40) }\end{array}$ & None & None \\
\hline $\begin{array}{l}\text { Labral } \\
\quad \text { sclerotization }\end{array}$ & $?$ & Complete & Complete & $\begin{array}{l}\text { Basal, transverse, } \\
\text { becoming dark }\end{array}$ & $\begin{array}{c}\text { Basal, transverse, } \\
\text { pigmented }\end{array}$ \\
\hline $\begin{array}{l}\text { Labral apical } \\
\text { margin }\end{array}$ & $?$ & Out-curved & $\begin{array}{c}\text { Slightly out-curved to } \\
\text { faintly } \\
\text { emarginated } \\
\text { (fig. 42) }\end{array}$ & $\begin{array}{c}\text { Narrowly } \\
\text { emarginated } \\
\text { medially (fig. 51) }\end{array}$ & $\begin{array}{c}\text { Broadly emarginated } \\
\text { medially (fig. 57) }\end{array}$ \\
\hline \multicolumn{6}{|l|}{ Mandibular } \\
\hline pigmentation & Absent & Dark & Dark & Dark only apically & Dark only apically \\
\hline $\begin{array}{l}\text { No. mandibular } \\
\text { teeth }\end{array}$ & $1 ?$ & $\begin{array}{c}1+\text { outer } \\
\text { subapical spine }\end{array}$ & 1 & 2 & 2 \\
\hline $\begin{array}{l}\text { Basal mandibular } \\
\text { spines }\end{array}$ & $?$ & $\begin{array}{l}\text { Pronounced } \\
\text { (figs. } 34,60 \text {, } \\
61 \text { ) }\end{array}$ & $\begin{array}{c}\text { Reduced (figs. 62, } \\
63 \text { ). }\end{array}$ & $\begin{array}{l}\text { Reduced } \\
\text { (figs. 64, 65) }\end{array}$ & $\begin{array}{l}\text { Present, bearing } \\
\text { conspicuous setae } \\
\text { (figs. 66, 67) }\end{array}$ \\
\hline Mandibular shape & $\begin{array}{l}\text { Apically } \\
\text { tapering, } \\
\text { not fanglike } \\
\text { (fig. 32) }\end{array}$ & $\begin{array}{l}\text { Apically curved, } \\
\text { fanglike } \\
\text { (fig. 61) }\end{array}$ & $\begin{array}{l}\text { Apically curved, } \\
\text { fanglike (figs. } 6 \text {, } \\
45 \text { ) }\end{array}$ & $\begin{array}{l}\text { Less curved, } \\
\text { not fanglike, } \\
\text { gradually } \\
\text { tapering in outer } \\
\text { view (fig. } 64 \text { ) }\end{array}$ & $\begin{array}{c}\text { Less curved, widening } \\
\text { subapically in outer } \\
\text { view (fig. } 66 \text { ) }\end{array}$ \\
\hline $\begin{array}{l}\text { Hypostomal } \\
\text { tubercle }\end{array}$ & $?$ & $\begin{array}{l}\text { Conspicuous } \\
\text { (figs. 35, 37) }\end{array}$ & $\begin{array}{l}\text { Conspicuous, even } \\
\text { longer than in } \\
\text { second instar } \\
\text { (figs. 42-44) }\end{array}$ & $\begin{array}{l}\text { Smaller } \\
\text { (figs. 52, 53) }\end{array}$ & $\begin{array}{l}\text { Almost absent } \\
\text { (figs. 57, 58) }\end{array}$ \\
\hline $\begin{array}{l}\text { Maxillae and } \\
\text { labium }\end{array}$ & $?$ & $\begin{array}{l}\text { Mostly } \\
\text { nonsclerotized }\end{array}$ & $\begin{array}{l}\text { Fused, sclerotized, } \\
\text { bridging parietals } \\
\text { (figs. } 39,40)\end{array}$ & $\begin{array}{l}\text { Normal sclerites, } \\
\text { no ventral bridge }\end{array}$ & $\begin{array}{c}\text { Normal sclerites, no } \\
\text { ventral bridge }\end{array}$ \\
\hline Body setae & Absent & Absent & Absent & $\begin{array}{l}\text { Minute, } \\
\text { inconspicuous }\end{array}$ & Present, conspicuous \\
\hline $\begin{array}{l}\text { Spiracle, abd. } \\
\text { segment } 8\end{array}$ & $?$ & Large (fig. 31) & Large (fig. 50) & Normal (fig. 56) & Normal (fig. 59) \\
\hline
\end{tabular}

(figs. 9, 20, 23); micropyle a cluster of pores on normally curved surface of front of egg/oocyte near anterior pole (fig. 22), but not visible under stereomicroscope. Egg color white; chorion under stereoscope clear, shiny, glassy, thicker, and stiffer at least dorsally than that of eggs of solitary bees; under SEM examination dorsal chorion thicker, with rougher surface (figs. 20, 21) than thin, smoother ventral chorion (fig. 23) and with frontodorsal area around micropyle not elevated; this area with raised, radiating reticulate pattern that fades completely immediately posterior to anterior end (figs. 21-23); where dorsal and ventral surfaces meet, chorion produced as an elevated, pitted, rounded ridge (figs. 22, 21, 23) that circumscribes egg/oocyte lengthwise; this ridge bending down under micropylar area at anterior end, so that front end of oocyte partly covered by thicker dorsal chorion (figs. 21-23).

Material Studied: One egg; two eclosed egg chorions; and ca. four large mature oocytes and numerous mature, smaller oocytes from two females.

REMARKS: The thick nature of the dorsal surface of the oocyte presumably helps shield the egg from attacks by the host female or females of other cleptoparasites. We were able to confirm the orientation of deposited eggs from several photographs, and note that, in 

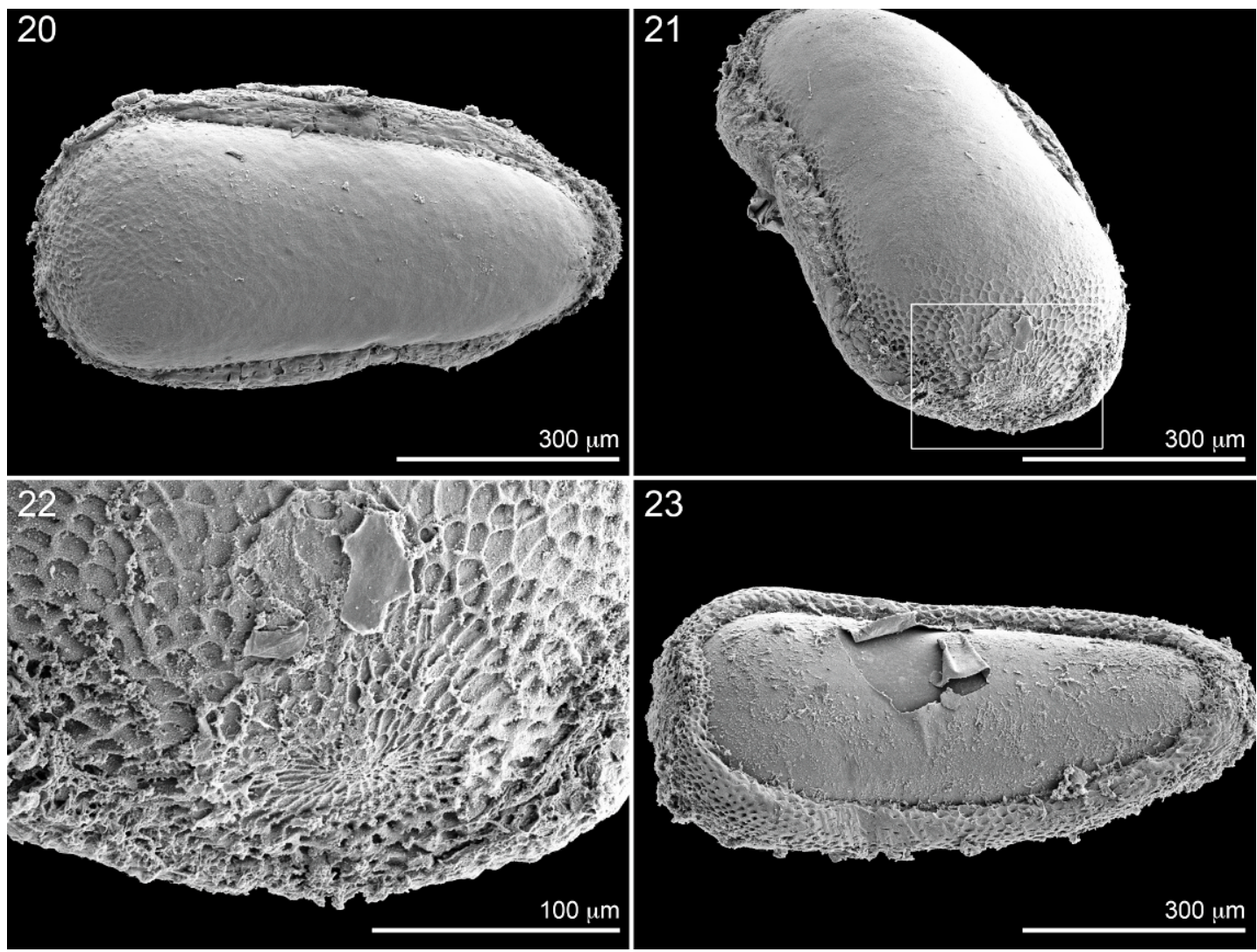

Figs. 20-23. SEM micrographs of mature oocytes of Coelioxys chichimeca. 20, 21. Entire oocyte, dorsal and anterodorsal views, respectively. 22. Close-up of micropylar area of 21. 23. Entire oocyte, near ventral view, demonstrating thinness of torn ventral chorion, near ventral view.

the only two eclosions observed, the second instars emerged upside down, i.e., with their dorsal surface facing the cell walls (figs. 11, 12) and their ventral surface visible through the chorion from the interior of the brood cell. The micropylar area is covered with a raised network of polygons, which become elongated near the anterior pole and which gradually fade posteriorly before the maximum diameter of the oocyte.

\section{First LARVAL INSTAR}

\section{Figure 32}

The first instar of this species is known from a single cast exuviae, with the only discernable feature a pair of mandibular apices (fig. 32). At the presumed outer base of each is a single sharply pointed projection (fig. 32). The ho- mologies of these two sharp points are uncertain as they might be near the outer bases of the mandibles or they might relate to the hypostomal tubercles of subsequent instars. Mandibles are pointed, but not sharply so, and only gently curved, an indication that they would be incapable of attacking a host egg or larva even if the first instar were not encased in the egg chorion. Head capsule and associated internal head ridges are not evident, also implying that these mandibles do not have substantial muscular support and therefore could not be used offensively.

\section{Second Larval Instar}

Figures 24-31, 33-37, 60, 61

Diagnosis: See table 1. Baker et al. (1985) described and illustrated the head of the 
second instar of Coelioxys (Cyrtocoelioxys) modesta Smith. The basal mandibular spines were similar (though perhaps somewhat less pronounced) to those of $C$. chichimeca, and $C$. modesta also has a subapical spine on what seems to be the outer surface of the mandible. Unfortunately, the authors offered no information about spiracle size.

Description: Head: Integument of head capsule, mandibles, and labrum heavily sclerotized and darkly pigmented. Head more or less hypognathous (fig. 35); sclerotization of parietals ending at postoccipital ridge; head not swollen, cranial swelling index 0.73 ; widest part of cranium in dorsal/ventral view in posterior half. Hypostomal tubercle (fig. 37) well developed, bearing several tuberculate sensilla without apical setae. Hypostomal ridge conspicuous, but other internal head ridges less evident because of dark, thick sclerotization of head capsule. Antennal papilla apically bilobate (fig. 36). Labral apex curved when viewed from above; labral sclerite covering most of dorsal surface of labrum, folding around sides, and bending over apex below level of tuberculate sensilla much as in third instar (fig. 42); sclerite apparently not fused to clypeus but closely applied to it so that their two surfaces cannot articulate, thus presumably forming solid base against which mandibles can squeeze host egg or larva.

Mandibular base broad but short, apically bearing approximately six large projecting spines on outer surface (fig. 34); beyond base, mandible tapering evenly to single, thin, strongly curved, sharply pointed apex; outer surface of apical part of mandible with single long, tapering, semierect, subapical, spine (fig. 34). Labiomaxillary region recessed, projecting little ventrally in lateral view (fig. 35), its apex well behind labral apex; its posterior margin in line with posterior tentorial pits in lateral view. Maxilla apically produced as distinct lobe with apical, well-defined palpus about as long as basal diameter; maxillary sclerites not evident. Labium with faint, irregularly shaped premental sclerite (fig. 24) near base, behind and laterad of which postmentum fuses indistinguishably with maxilla (fig. 34); palpi well defined, about as long as basal diameter. Paired hypopharyngeal lobes (fig. 24) present as lateral dome-shaped structures present at apex of labium well above and slightly laterad of palpi in line with salivary opening. ${ }^{6}$ Salivary opening and duct evident (fig. 24).

Body: Integument with fine spicules. Body form (fig. 33) elongate, linear, parallel-sided except abdominal segments 9 and 10 (fig. 33), which have reduced diameters and are short compared with other body segments. Diameter of atrial opening of thoracic spiracles and spiracles of abdominal segments 1-5 subequal, but atrial opening of other abdominal spiracles (figs. 28-31) increasing incrementally in diameter, so spiracles of abdominal segment 8 (fig. 31) approximately four times that of thoracic spiracles and those of abdominal segments 1-5 (fig. 28); on cleared specimen, diameter of atrium approximately twice ${ }^{6}$ that of those of thoracic spiracles and abdominal segments 1-5; atrial wall (fig. 27) bearing jagged, transverse denticles arranged concentrically around primary spiracular opening; subatria (figs. 25, 26) tapering, at least those of posterior spiracles annulated; diameter of lateral tracheal trunk (fig. 25) in posterior half of abdomen approximately same as diameter of atrium on abdominal segment 1 .

Material Studied: Fewer than eight second instars; numerous cast exoskeletons.

\section{THIRD LARVAL INSTAR}

Figures 38-50, 62, 63

\section{Diagnosis: See table 1.}

DESCRIPTION: Head: As described for second instar except for following: Head (figs. 40, 43) somewhat more prognathous because of posterior extension of sclerotization of parietal (fig. 40) and of posterior boundary of ventral surface of head capsule (fig. 39) including labiomaxillary region (see below); sclerotization of parietals extending posteriorly short distance behind postoccipital ridge as seen on cleared head capsule in lateral view (fig. 40); head substantially swollen, cranial

\footnotetext{
${ }^{6}$ The identification of the hypopharyngeal lobes was uncertain because of their position so far forward on the labial apex in the second instar but was confirmed in the third instar by its more pronounced lobes, now farther back relative to the position of the salivary opening.
} 

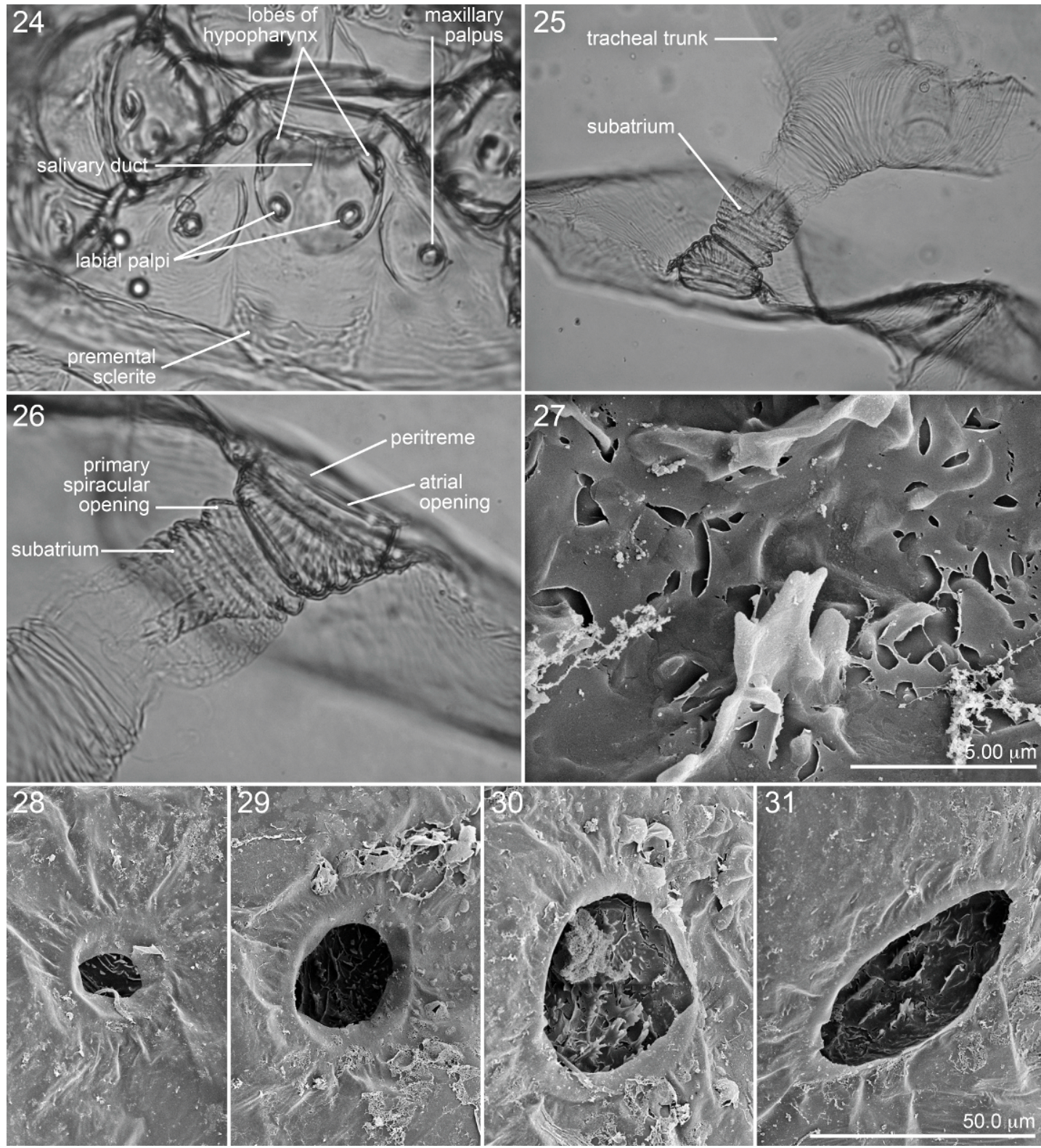

Figs. 24-31. Microphotographs of cleared exoskeleton of second instar of Coeliooxys chichimeca. 24. Mouthparts, frontal view, showing lobes of hypopharynx. 25. Spiracle and section of lateral tracheal trunks. 26. Close-up of spiracle showing details of atrium, chamber of primarily spiracular opening, and subatrium, side view. Figs. 27-31. SEM micrographs of spiracles of abdominal segments 5-8, respectively, showing size increases. 27. Close-up of atrial wall identified by rectangle in fig. 31. 28-31. Exterior views of spiracles on segments 5-8 respectively, to same scale, showing size increase.

swelling index 0.67 ; widest part of cranium in dorsal/ventral view in anterior half, shortly behind hypostomal tubercles. Hypostomal tubercle (figs. 42-44) attenuate, more pro- nounced than in second instar, with tuberculate sensilla each bearing elongate, sharppointed seta (fig. 44). Antennal papilla (fig. 46) elongate, apex not bilobed. Labral 

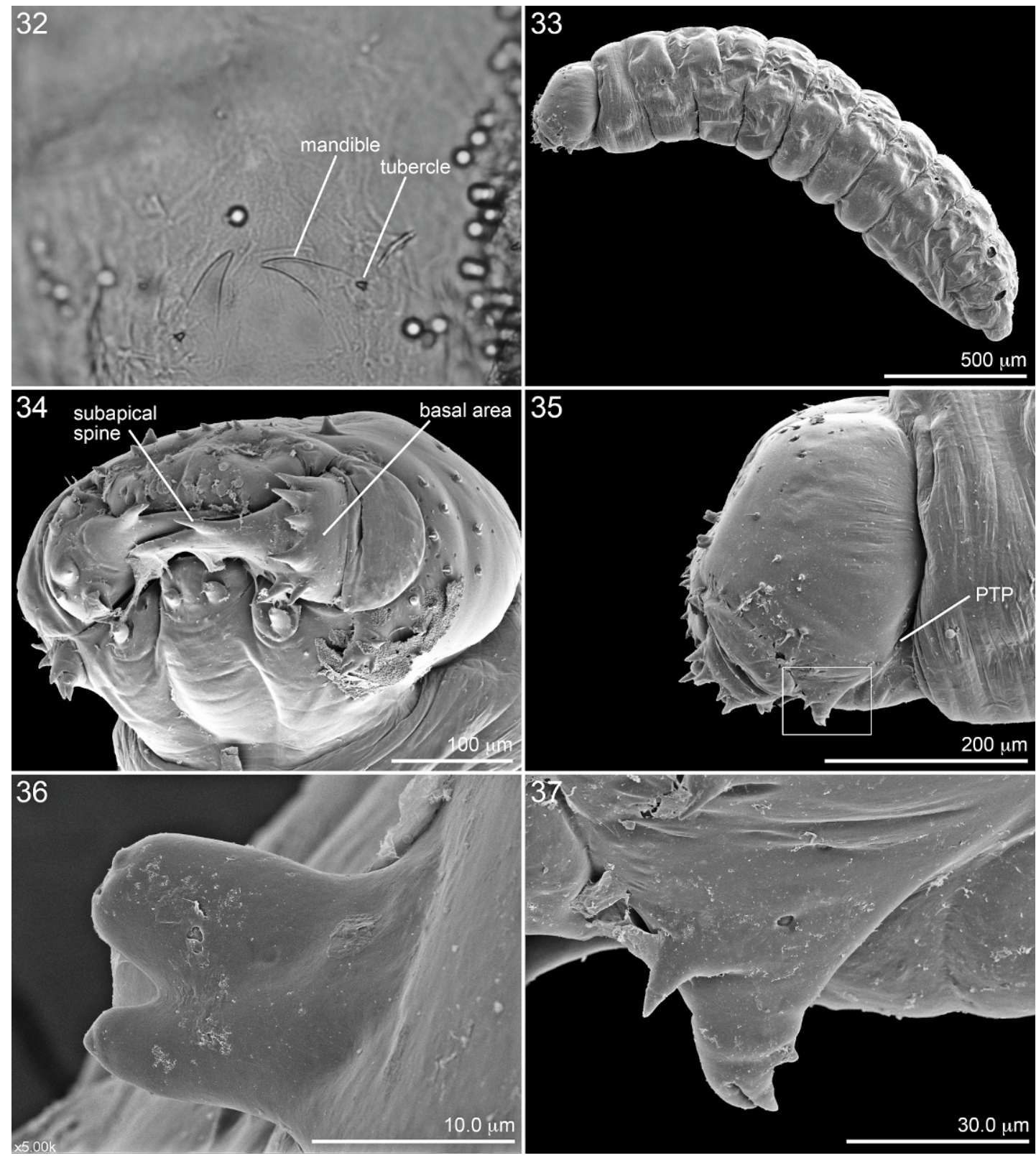

Fig. 32. Microphotograph of cast exuviae of first instar of Coelioxys chichimeca appressed to inner surface of chorion, showing mandibular apices and small tubercle at outer base of each. Figs. 33-37. SEM micrographs of second instar of Coelioxys chichimeca. 33. Entire larva, lateral view, showing reduced abdominal segments 9 and 10 and enlarged spiracles on abdominal segments 6-8. 34. Head, near frontal view from below, showing armature of base of mandible and spine on outer surface of apical part of mandible. 35. Head, lateral view. PTP $=$ posterior tentorial pit. 36. Antenna, lateral view. 37. Close-up of hypostomal tubercle identified by rectangle in figure 35 . 

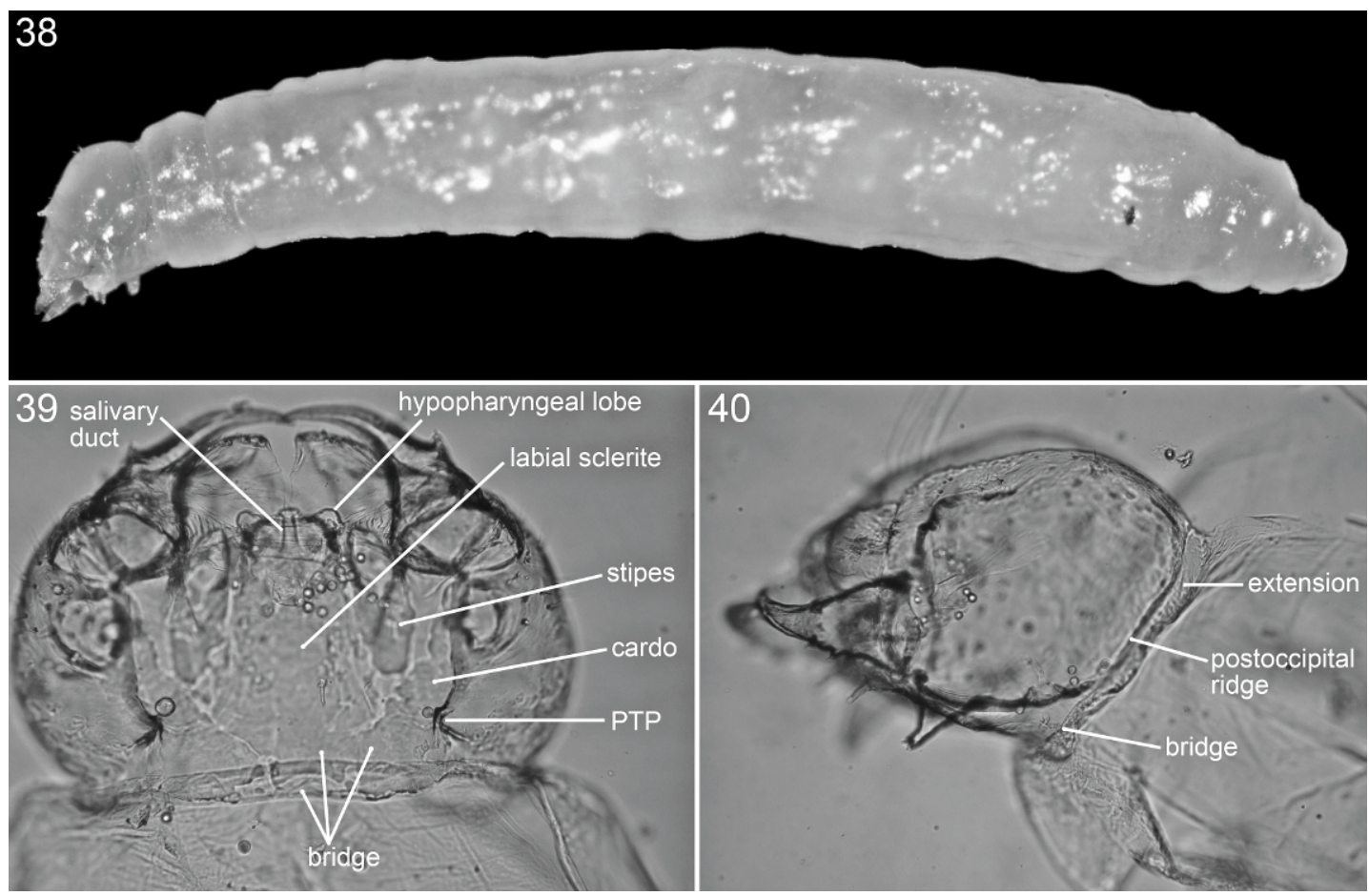

Figs. 38-40. Microphotographs of third instar of Coelioxys chichimeca. 38. Entire larva, lateral view, showing elongate shape, constriction behind head, reduced size of abdominal segments 9 and 10. 39. Head of cast skin, ventral view, showing sclerites of labiomaxillary region, hypopharyngeal lobes, and postoccipital bridge. 40. Same, lateral view, showing posterior extension of parietal, cardo, and labium to form ventral postoccipital bridge. PTP $=$ posterior tentorial pit.

apex (fig. 42) in frontal view gently outcurved to nearly straight to faintly emarginated depending on angle of viewing, bearing row of tubercles along extreme apical margin; entire dorsal labral surface sclerotized.

Mandible (fig. 45) attenuated, more elongate than that of second instar with basal part longer and seemingly more gradually tapering into apical part of mandible; basal spinelike tubercles smaller; subapical spine on outer surface of mandible completely absent; apical part of mandible sharply curved near simple apex as seen from above or below (figs. 45, 62). Labiomaxillary region recessed both ventrally and apically (fig. 39, 40, 42, 43); this surface tending to be planar except at apical end where contours of apical part of stipites and prementum somewhat defined. Maxillary sclerites (fig. 39) faint but evident on cleared specimen or skin; cardo presumably a large plate, broadly fused to parietal along entire length of hypostomal ridge; this plate, with irregular edges, extending posteriorly short distance beyond posterior tentorial pit so that laterally it joins posterior extension of parietals behind postoccipital ridge and mesad fuses with sclerotized labium to form postoccipital bridge; stipital sclerite with irregular edges articulating with cardo at one point. Labial sclerite weak (fig. 39), with anterior edge shortly behind palpi, extending posteriorly to posterior margin of head where it fuses with cardines, forming weak but complete postoccipital bridge (fig. 39); thus labium not divided into pre- and postmentum.

Body: As described for second instar except for following: Body form even more elongate (figs. 38, 41); abdominal segments 9 and 10 abruptly smaller than preceding segments in lateral view (fig. 38). Diameter of atrial opening of abdominal spiracle 8 (fig. 50) approximately eight times that of thoracic 

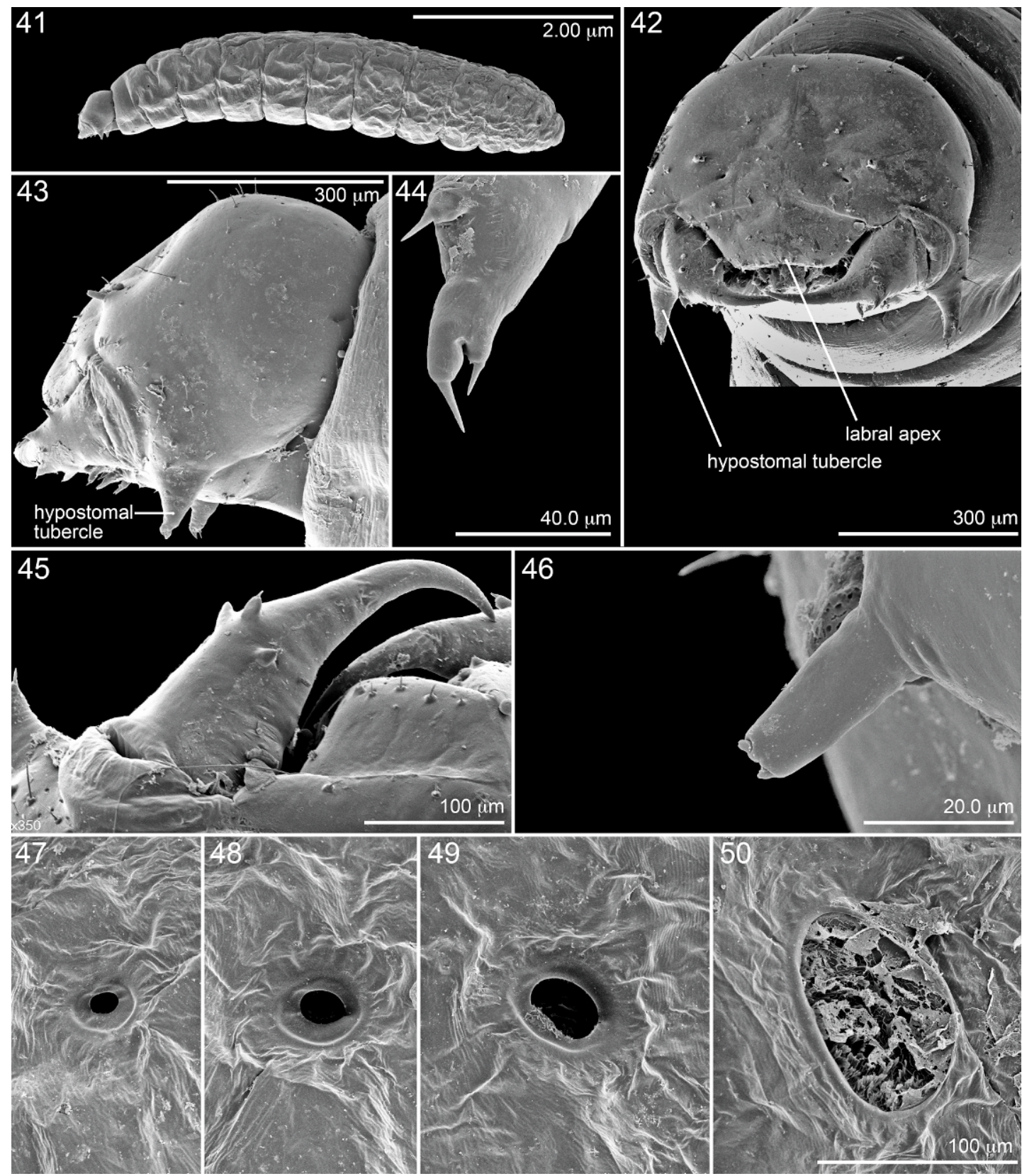

Figs. 41-50. SEM micrographs of third instar of Coelioxys chichimeca. 41. Entire larva, lateral view. 42. Head, near frontal view. 43. Head, lateral view. 44. Close-up of hypostomal tubercle of another specimen, showing setalike sensilla compared with those of second instar, 45. Left mandible, dorsal view showing reduced basal tubercles, absence of outer spine on apical part of mandible, and elongate, fanglike apex. 46. Antenna, lateral view. 47-50. Spiracles of abdominal segment 5-8, respectively, all to same scale, showing size increases of atrial opening; nature of material in 8th spiracle not understood but occurs in another specimen as well. 
spiracles and spiracles of abdominal segments 1-5 (fig. 47); atrial openings on abdominals 6 and 7 as illustrated (figs 48, 49).

Material Studied: Fewer than eight third instars; numerous cast exoskeletons.

REMARKs: In general, the third instar appears more highly anatomically adapted to its hospicidal role than the second instar although evidence indicates that either can be successful as a host killer. These anatomical features include the slight elongation of the head resulting from sclerotization behind the postoccipital ridge, the development of a complete ventral postoccipital bridge, more extensive sclerotization of the labiomaxillary sclerites, and the more elongate mandibles.

\section{FOURTH LARVAL INSTAR}

Figures 51-56, 64, 65

Diagnosis: See table 1.

DESCRIPTION: As described for second and third instars except for following: Integument only faintly pigmented except for mandibular apices, which are darkly pigmented and for premental sclerite, which is only moderately pigmented. Head capsule normally hypognathous (fig. 52); posterior extension of sclerotization of parietals not evident, appearing only as rim to foramen magnum in conjunction with postoccipital ridge; posterior tentorial pit at posterior margin of head capsule. Head capsule less swollen; cranial index 0.74; widest part of cranium in dorsal/ventral view in approximate middle of head. Hypostomal tubercle (fig. 53) stouter but still projecting, with tuberculate sensilla far less pronounced. Antennal papilla (fig. 54) still pronounced. Labral apex deeply emarginated medially in frontal view (fig. 51); leading apical edge of labrum membranous behind which labral sclerite present.

Mandible (fig. 55) apically bidentate, with ventral tooth longer than dorsal one and both sharply pointed; dorsal tooth finely serrated along upper apical edge; mandibular apex broader than in second and third instars; in outer or inner views mandible gradually, evenly tapering (fig. 65), without subapical constriction as in fifth instar (fig. 67); inner apical surface scoop shaped forming apical concavity; upper apical margin uneven, faint- ly, unevenly serrate; cuspal area not developed, without denticles; tubercles on outer surface small, each bearing short setiform sensillum. Labiomaxillary region (fig. 52) projecting more ventrally and apically, so that apex extends nearly as far forward as labrum in lateral view (fig. 52); this region not planar, with maxillae projecting lobes separate from labium, and labium clearly divided into prementum and postmentum, as in fifth instar. Maxillary sclerites consisting of simple oval cardo, articulating with head capsule only at posterior tentorial pit and with stipes. Labial sclerotization restricted to premental sclerite; postmentum not sclerotized, so that postoccipital bridge absent.

Body: Form elongate, but posterior part becoming physogastric and abdominal segments no longer suddenly reduced in diameter in lateral view. Atrial diameter of all spiracles subequal (fig. 56); peritreme without rim; lateral tracheal trunks enlarged.

Material Studied: Fewer than four fourth instars; numerous cast exoskeletons.

\section{FifTh LARVAL INSTAR}

Figures 57-60, 66-68

Diagnosis: See table 1.

DESCRIPTION: We compared the fifth larval instar of Coelioxys chichimeca with two postdefecting larvae of $C$. (Cyrtocoelioxys) modesta Smith (Florida: Lake Placid, X-61959, III-21-1960 [K.V. Krombein]) identified by the collector. Although not cleared, they were indistinguishable from $C$. chichimeca including having greatly reduced hypostomal tubercles. The one preserved in March exhibited a large, dark median spot on its apical labral margin, and the other bore a faint brownish spot there, presumably indicating that it had recently reached its postdefecating stage when preserved.

Although the fourth instar of Coelioxys chichimeca possesses conspicuous hypostomal tubercles, these tubercles are virtually absent in its last instar; they are represented only by a sharp angle where the pleurostomal and hypostomal ridges meet in lateral view (figs. 57, 58). Another identifying feature of mature Coelioxys larva is the large single 

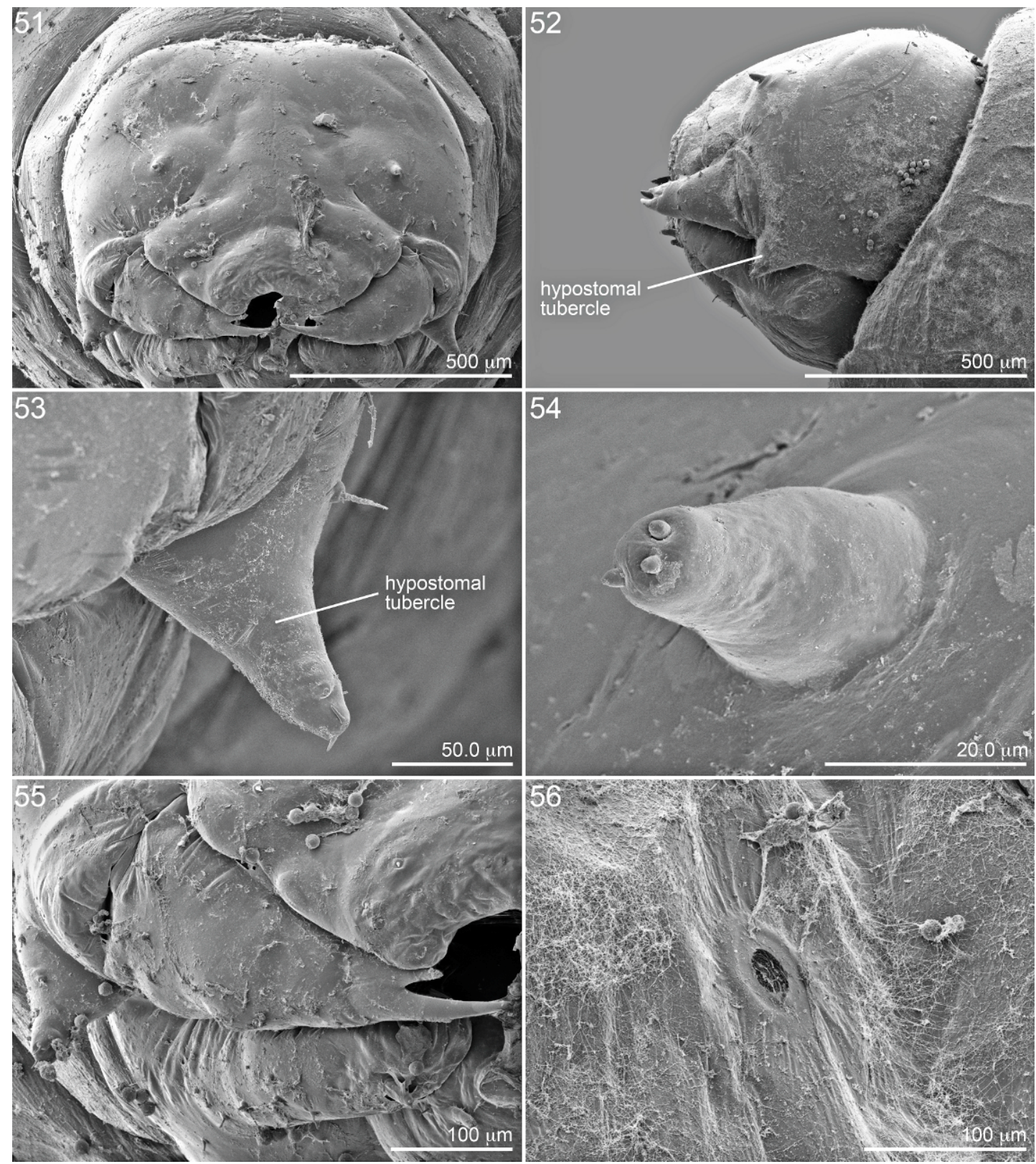

Figs. 51-56. SEM micrographs of fourth instar of Coelioxys chichimeca. 51. Head, frontal view. 52. Head of another specimen, lateral view. 53. Hypostomal tubercle, frontal view, with sensilla greatly reduced in size. 54. Antenna, approximate frontal view. 55. Right mandible, outer view. 56. Spiracle.

median dark spot on the clypeal apex (as in Rozen and Kamel, 2007: figs. 44, 45). With $C$. chichimeca this character appears only on the postdefecating larva, and not on predefecating forms. As is apparently true of all megachilids, long body setae are found only on the last larval instar, and the slitlike salivary lips are projecting; thus, this instar is easily distinguished from earlier ones. Mature larvae of $C$. chichimeca are easily separated from those of 

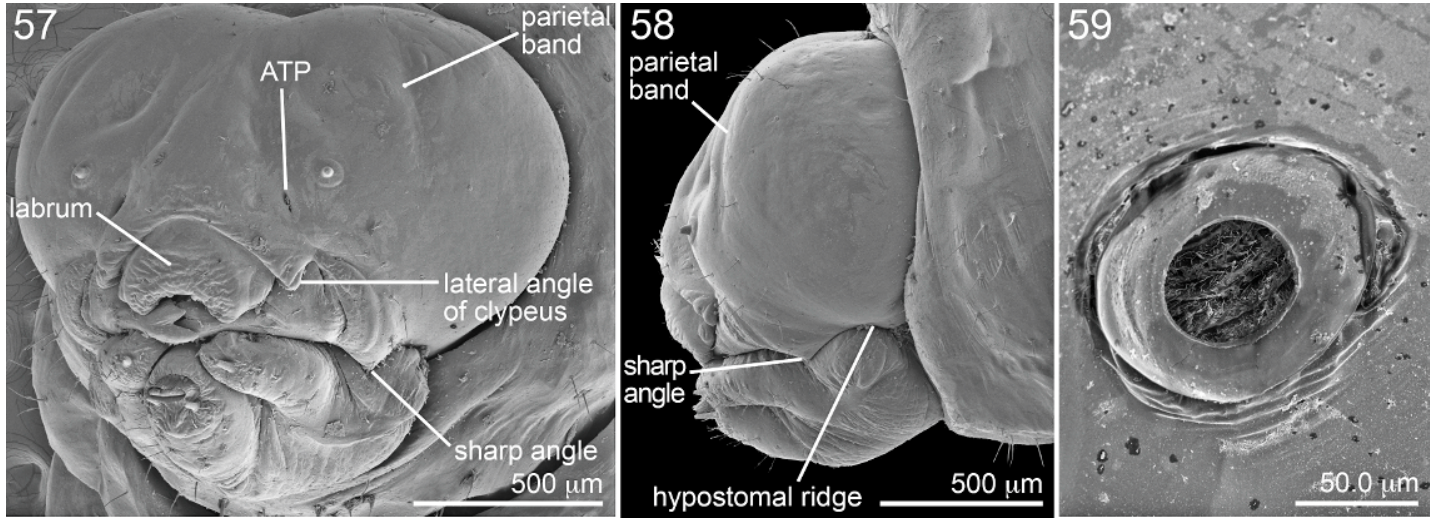

Figs. 57-58. SEM micrographs of fifth instar of Coelioxys chichimeca. 57. Head, near frontal view. 58. Head, lateral view. 59. Spiracle, now with rim.
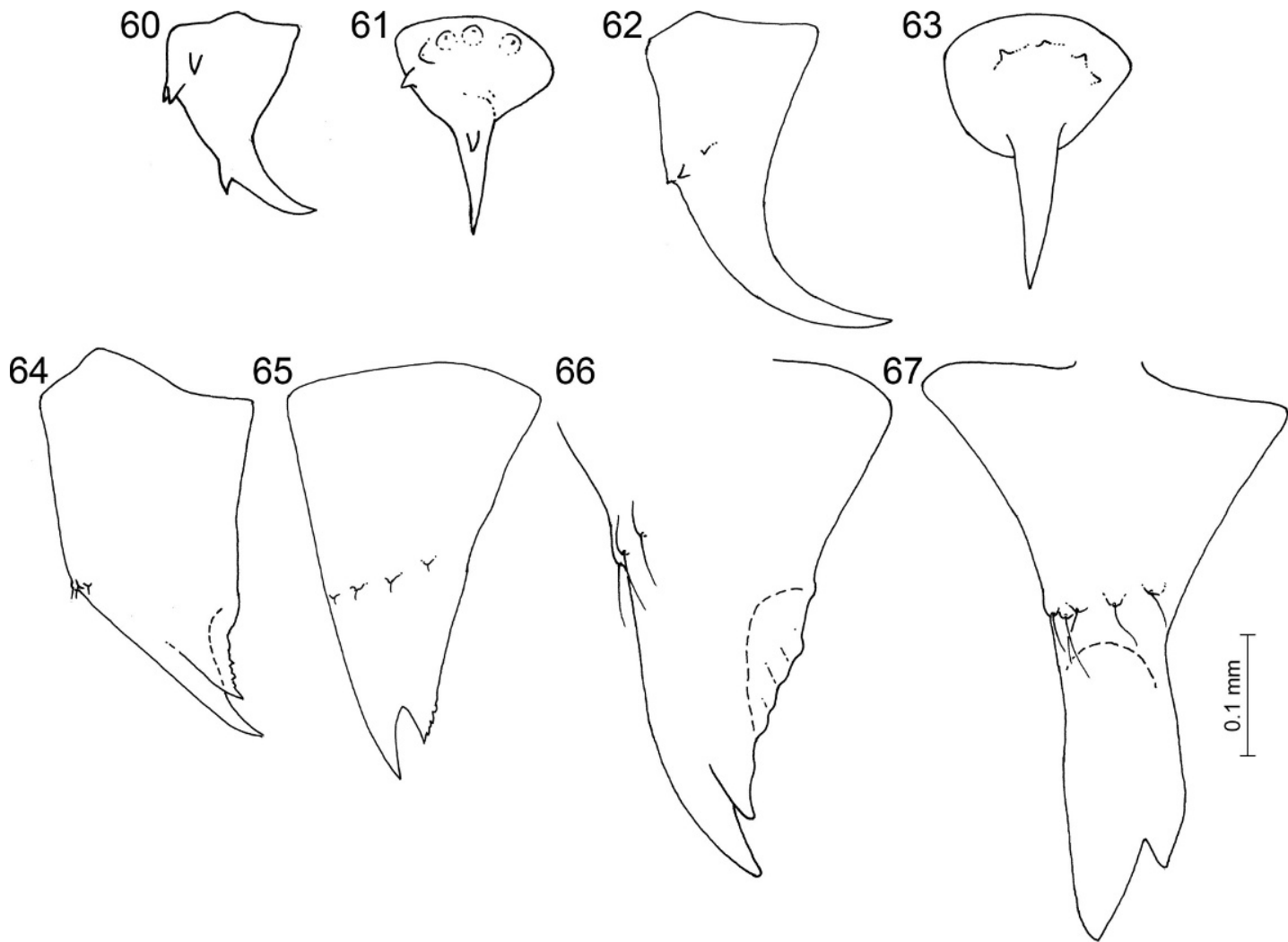

Figs. 60-67. Right mandible of larval instars 2 -5 of Coelioxys chichimeca, respectively, dorsal and outer views; latter with their apices in maximum profile (all to same scale). 

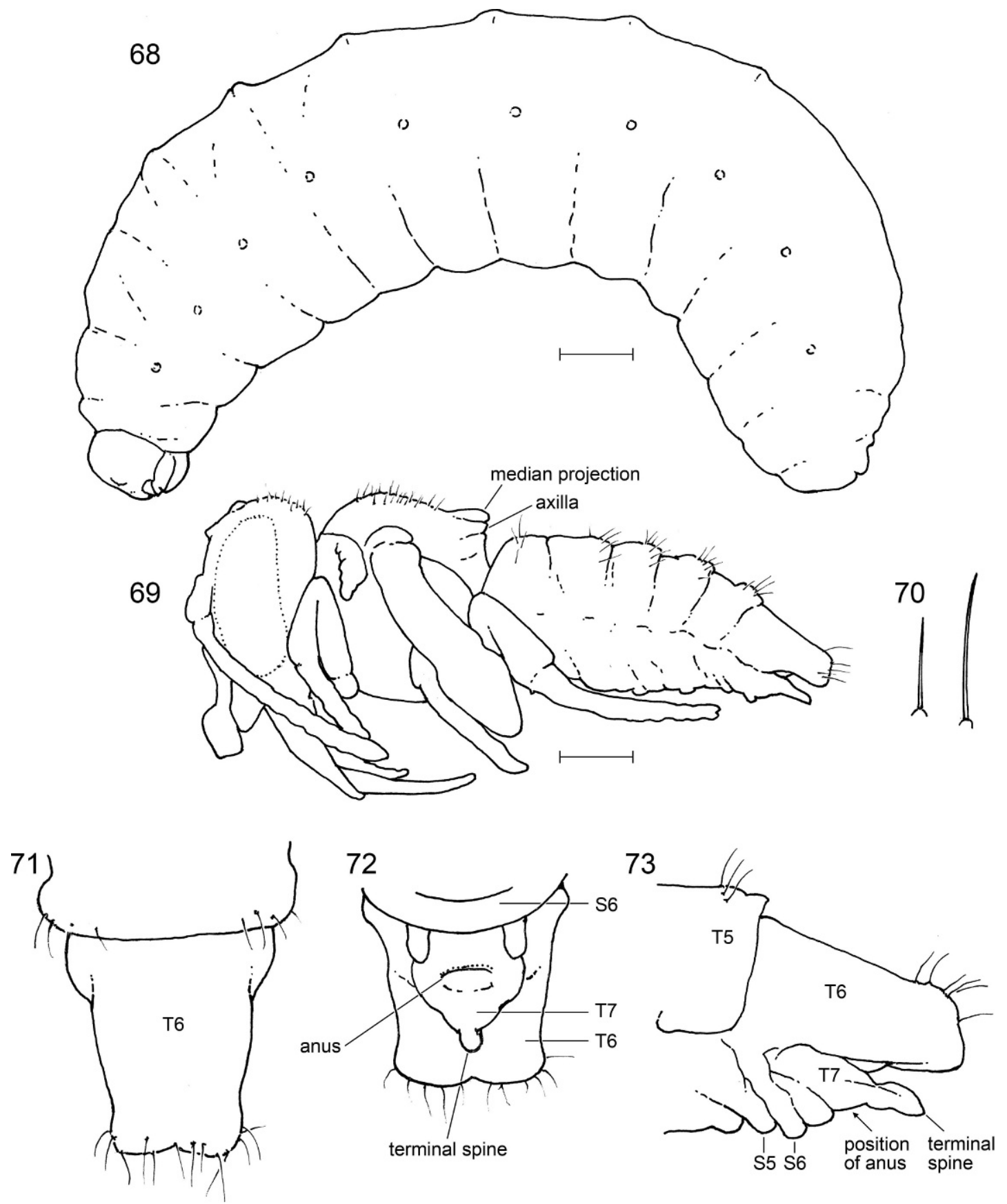

Figs. 68-73. Diagrams of immatures of Coelioxys chichimeca. 68. Entire fifth larval instar, lateral view (scale $=1 \mathrm{~mm})$. 69. Male pupa, lateral view (scale $=1 \mathrm{~mm})$. 70. Length of longest seta from pupal mesoscutum (left) compared with that from metasomal T2 (right). 71-73. Enlarged metasomal apex of male pupa, dorsal, ventral, and lateral views, respectively, in maximum profile, all to same scale. 
the host, Centris bicornuta, by the different shape of the mandibles (figs. 66, 67), by the lack of body setae in C. bicornuta, and by the labral apex being broadly emarginate in $C$. chichimeca (fig. 57), rather than broadly rounded as in $C$. bicornuta.

Because the last larval instar of Coelioxys chichimeca matches the preliminary description of the mature larvae of the Megachilini given by Rozen and Kamel (2007: 19, 20), the shared features are not repeated below.

Head: On postdefecating larva, labrum with conspicuous median, darkly pigmented mark extending from apical margin to labral sclerite, which is also pigmented; on predefecating larva, apical labral margin unpigmented except for several apical, paramedial sensilla. Head hypognathous (fig. 58), little swollen, cranial swelling index 0.84 ; widest part of cranium approximately in middle in dorsal/ ventral view. Anterior tentorial pit (fig. 57) somewhat closer to antennal papilla than to anterior mandibular articulation; posterior tentorial pit well impressed, in normal position at junction of hypostomal and postoccipital ridges. Median longitudinal thickening of head capsule evident only on top of head, fading completely well above level of antennae. Postoccipital, hypostomal, and pleurostomal ridges well developed; hypostomal ridge strongly curved downward at both ends (fig. 58); hypostomal tubercle virtually absent, but junction of pleurostomal and hypostomal ridges sharply but obtusely angled (figs. 57, 58). Parietal band faint, scarcely evident. Clypeus with apical lateral angle projecting down, so that apex of clypeus considerably broader than base of labrum (fig. 57). Labral sclerite a basal transverse band more or less well pigmented.

Mandible (figs. 66, 67) moderate in length, robust, with two broad apical teeth; in outer or inner views mandible slightly constricted subapically, so that mandibular apex somewhat broader than constricted area (fig. 67); inner apical surface with elongated, moderately deep apical concavity with well-defined basal boarder; upper apical margin uneven, faintly crenulated; cuspal area not developed, without denticles; outer mandibular surface with cluster of 5-6 small tubercles each bearing elongate seta; these tubercles closer to mandibular base than to apex, presumably homologous with basal mandibular tubercles of earlier instars. Labiomaxillary region moderately weakly projecting in lateral view (fig. 58). Maxilla unremarkable for megachilid larva. Labial apex moderately narrow; labial palpus and maxillary palpus subequal in length. Salivary opening a moderate narrow transverse slit on projecting lips.

Body (figs. 68): Known only from predefecating larva. Much of body with conspicuous, rather sparse, tapering, moderately long setae arising from conspicuous alveoli; pleural area of abdominal segment 8 with only about 4-6 setae. Body form robust (fig. 68); intersegmental lines weakly incised; dorsal intrasegmental lines (separating cephalic and caudal annulets) nearly absent on cleared and uncleared specimens; ventral intersegmental lines moderately weakly incised; pleural swellings not protuberant. Spiracles (fig. 59) moderately large, faintly pigmented, subequal in size; atrium globular, projecting above body wall, with rim; peritreme present, about half as wide as atrial opening; atrial inner surface densely covered with rows of irregular denticles concentric with primary tracheal opening; maximum external diameter of chamber of primary tracheal opening somewhat less than that of atrium; chamber without denticles or possibly with short denticles; subatrium as wide as, or wider than, maximum diameter of atrium, with approximately eight very short chambers that fade as they recede from body surface; constrictions between chambers each with row of denticles; diameters of lateral tracheal trunks larger than diameter of atrium.

Material Studied: One cast exoskeleton of postdefecating larva; six predefecating larvae.

Remarks: As is usually the case with last instars of larval bees, head pigmentation of the fifth instar increases as they feed and grow. Recently emerged fifth instars are much paler (almost colorless except for mandibular apices) than the later fifth instar described above and illustrated (fig. 68). On the other hand, the middorsal body tubercles of smaller, younger fifth instars are more conspicuous than those the older larva illustrated (fig. 68). 
PUPA

Figures 69-73

Diagnosis: Because of its elongate T6 and posterior median mesoscutellar projection, the male pupa of Coelioxys chichimeca can be distinguished from that of $C$. (Boreocoelioxys) sayi Robertson, which has a much shorter T6 and no posterior median mesoscutellar projection (Baker et al., 1985: fig. 6, A, B). Because of its elongate T6, the male pupa of C. chichimeca can also be separated from that of C. (Allocoelioxys) coturnix (Pérez) (Rozen and Kamel, 2007: fig. 74), as well as from that of the related Radoszkowskiana rufiventris (Spinola) (ibid.: fig. 76).

The following description follows the format of the pupal descriptions in Rozen and Kamel (2007).

Head: Vertex with conspicuous, mostly long, erect setae that do not extend below level of median ocellus; supraclypeal area lacking median tubercle, other tubercles and verrucae lacking. Discal area of labrum protuberant (accommodating erect adult setae) as seen in lateral view (fig. 69); pupal ocelli well defined. Mandible simple, with only slight ventral swelling for developing adult setae.

Mesosoma: Mesoscutum with conspicuous, long setae, many rising from small tubercles; mesoscutellum without setae. Lateral angle of pronotum not defined; lateral lobe of pronotum weakly projecting, with lower apical surface produced as small rounded lobe. Mesoscutum without tubercles or verrucae; mesoscutellum with posterior margin produced posteriad, ending in median, low, rounded projection; axillae projecting posteri$\mathrm{ad}$, their apices in line with median projection of mesoscutellum in lateral view (fig. 69); metanotum with small median swelling; area around propodeal spiracle apparently swollen but not tuberculate; mesepisternum without tubercles. Tegula not produced, without tubercles or verrucae; wings without tubercles. All coxae without tubercles; foretrochanter little modified; mid- and hind trochanters slightly swollen apically; other leg segments unmodified.

Metasoma: Terga with subapical transverse bands of conspicuous, often long setae (fig. 69) that are substantially longer than those (fig. 70) of mesoscutum, some rising from minute tubercles, distributed as follows: $\mathrm{T} 1$ with band of fewer setae than on T2; setae erect, tending to be found sublaterally; T2-T5 with bands more complete than on T1, most found sublaterally, these setae erect or curving posteriad; T6 with long setae apically, pointing posteriad. T6 elongate, as seen in lateral view (fig. 73), much longer than T5, approximately as long as maximum width as seen in dorsal view, with bilobed posterior margin (figs. 71, 72); T6 extending posteriad farther than apex of terminal spine, as seen in lateral view (fig. 73). Sterna without conspicuous setae. Apex of metasoma with terminal spine above anus (figs. 72, 73).

Material Studied: One male pupa.

\section{DISCUSSION}

Recent studies ${ }^{7}$ have revealed two modes of cleptoparasitism in Coelioxys. In the one that may be more common, the female Coelioxys invades the host cell while it is being provisioned and hides her egg in the cell lining or in the provisions (Baker, 1971; Carré and Py, 1981; Rozen and Kamel, 2006). The first instar remains shrouded in the egg chorion and presumably does not feed on provisions. The second instar sloughs off the chorion with the exoskeleton of the first instar, and feeds on provisions. Its head capsule is heavily sclerotized as are its somewhat enlarged mandibles. As a third (but perhaps also second) instar, the larva encounters and kills the host offspring. The third instar has an extremely aggressive behavior and head features that are even more exaggerated (including huge mandibles and prognathous head) than those of the second. The two subsequent instars, with the anatomy of a typical megachilid-type larva, complete feeding on provisions. Examples of this mode of cleptoparasitism are found in the following subgenera: Coelioxys (Iwata, 1939), Allocoelioxys (Carré and Py, 1981), Cyrtocoelioxys (present paper), Boreocoelioxys (Baker, 1971), and Liothyrapis (Rozen and Kamel, 2007).

\footnotetext{
${ }^{7}$ Earlier studies of Coelioxys usually overlooked or confused various larval stadia, resulting in misinterpretations of the modes of cleptoparasitism in the genus.
} 
In the second mode of parasitism, so far known in only two species of the subgenus Allocoelioxys (Ferton, 1896; Rozen and Kamel, 2008), ${ }^{8}$ the Coelioxys female enters the cell, presumably while the host female is gathering closure material to seal the cell, and deposits her egg on top of the host egg. The parasite embryo develops more rapidly than that of the host, and the first instar still partly or completely shrouded in its chorion bites through its chorion into the host egg. It then proceeds to ingest the contents of the host egg. Its mandibles are strongly curved and sharply pointed and bear a single semierect, sharply pointed spine subapically on the outer surface. All subsequent instars are provision feeders with the unremarkable anatomy of the typical megachilid-type larva.

Study of Coelioxys chichimeca shows that this species has a mode of parasitism similar to that of the first mode described above with some variations. When we first observed the larva emerging from the egg chorion as a second instar, we thought that this was unusual, but then realized that was true for other known Coelioxys, except with others the chorion was thin and seemed to dissolve with the shedding of the first instar exuviae. The unusual feature here was the thick, presumably protective dorsal chorion of the egg.

We have seen the massive array of spines on the outer surface of the second instar's mandibles only in diagrams of Coelioxys modesta (Baker et al., 1985: figs. 5C, D) and strongly suspect that at least in $C$. chichimeca they assist the emergence of the larva by rupturing the thick egg chorion. The semierect subapical spine on the outer surface is remarkably similar in position and appearance to the spine on the first instar Coelioxys coturnix (Rozen and Kamel, 2008), but knowledge of the anatomy of the first instar

\footnotetext{
${ }^{8}$ Of interest here is the fact that three consubgeneric species exhibit both modes of cleptoparasitism found in the genus. Coelioxys (Allocoelioxys) echinata Förster (= rufocaudata Smith) was reported by Carré and Py (1981) to have the more common of the two modes, whereas $C$. (A.) afra Lepeletier and $C$. (A.) coturnix Pérez were reported to exhibit the less common mode (Ferton, 1896, and Rozen and Kamel, 2008, respectively). This situation is further confused because the less common mode of parasitism is also known for the megachiline genus Radoszkowskiana (Rozen and Kamel, 2007).
}

of $C$. chichimeca is too limited to conjecture about homology. A more likely homology is between the subapical spine on the second instar mandible of $C$. decipiens Spinola (Rozen and Kamel, 2006) with that of $C$. chichimeca.

This form of eclosion, i.e., the second instar emerging from an aperture in the front end of the chorion almost certainly made with the larval mandibles, is in many ways similar to emergence in other species of Coelioxys except chorions of other species are much thinner and seem to be sloughed off with the first instar exuviae rather than being left behind in the thicker chorion. A phenomenon similar to that found in $C$. chichimeca has been noted for Dioxys cincta (Jurine) (Megachilidae) in that the second instar is the one that emerges (Rozen and Özbek, 2004, 2005) from a hole in the chorion, though how the hole is made is unknown.

The elongate body form, particularly of the third instar of Coelioxys chichimeca, seems unusual, but we suspect that it is adaptive, permitting the larva to search widely for the host immature while the posterior end of the larva is attached to the egg insertion pit, which in turn may be required by the need for air.

The unique feature of Coelioxys chichimeca is the modified respiratory system with enlarged spiracles at the posterior end of the abdomen and enlarged lateral tracheal trunks running through the body. Enlarged spiracles in hospicidal instars of cleptoparasitic bees were reported by Rozen (1991) for first instars of certain Isepeolus (Apidae: Isepeolini) and Mesoplia (Apidae: Ericrosidini). It is tempting to speculate that sharing of this feature by Mesoplia and C. chichimeca is related to their both being cleptoparasites of Centris. These two parasites might have evolved modification of their respiratory systems for overcoming a defense mechanism developed in Centris (such as covering pollen with a thick layer of nectar). However, the strategies are different as in the case of Mesoplia the egg chorion is not cast off but is attached full of air to the rear of the larva, and would seem to serve as a float on a liquid surface (Vinson et al., 1987; Rozen, 1991). We can offer no explanation at this time for the enlarged posterior spiracle in Isepeolus, a parasite of Colletes. 
The recent studies of the Coelioxys hint that its anatomical and behavioral variation is adaptive, enabling various species to attack hosts with different nesting strategies that may have arisen as defense mechanisms against parasitism. The large number of species of Coelioxys suggests that the genus has the evolutionary plasticity to adapt to the defense mechanisms of numerous groups of bees.

The hypothesized explanation of the role that nectar plays in dictating the mode of parasitism in Coelioxys chichimeca and perhaps related species deserves further investigation. One wonders whether the application of a thick layer of nectar is a defense strategy by which the ancestor of this species of Centris has evolved in response to attack by other cleptoparasites. If so, $C$. chichimeca has found a way to overcome it.

\section{ACKNOWLEDGMENTS}

J.G.R. is grateful to Robert G. Goelet for his ongoing support of Rozen's foreign field program to investigate the comparative biology of bees. All authors extend their appreciation to D.A.S. Stewart who permitted them to deploy their trap nests on his ranch, the Hacienda Monteverde. Without his cooperation this research could not have been carried out. We extend our thanks to Sean G. Brady and Brian Harris, Smithsonian Institution, for the loan of the two mature larvae of Coelioxys modesta.

S.E.M. examination of specimens was performed in the AMNH Microscopy and Imaging Facility (Rebecca Rudolph, Laboratory Manager) with the technical assistance of Mathew Frenkel. Our thanks also go to Steve Thurston who photographed specimens, drafted diagrams, and arranged and labeled all plates for publication.

We extend appreciation to two outside anonymous reviewers whose thoughtful comments and keen editing substantially improved the manuscript.

\section{REFERENCES}

Baker, J.R. 1971. Development and sexual dimorphism of larvae of the bee genus Coelioxys. Journal of the Kansas Entomological Society 44: $225-235$.
Baker, J.R., E.D. Kuhn, and S.B. Bambara. 1985. Nests and immature stages of leafcutter bees (Hymenoptera: Megachilidae). Journal of the Kansas Entomological Scoiety 58: 290-313.

Carré, S., and J.P. Py. 1981. Coelioxys rufocaudata Sm. (Hymenoptera, Megachilidae) cleptoparasite de Megachile rotundata F. (Hymenoptera, Megachilidae) pollinisteur de la luzerne. Apidology 12: 303-317.

Ferton, C. 1896. Nouvelles observations sur l'instict des hyménoptères gastrilégides de la Provence. Actes la Société Linnéenne de Bordeaux 48: 241-249, 1895.

Graenicher, S. 1905. Some observations on the life history and habits of parasitic bees. Bulletin of Wisconsin Natural History Society 3: 153-167.

Iwata, K. 1939. Biology of Coelioxys elongata Lepeletier. Mushi 12: 34-40.

Iwata, K. 1955. The comparative anatomy of the ovary in Hymenoptera. Part I. Aculeta. Mushi 29: $17-34$.

Iwata, K. 1965. The comparative anatomy of the ovary in Hymenoptera (records on 64 species of Aculeata in Thailand with descriptions of ovarian eggs). Mushi: 101-111.

Iwata, K., and S.F. Sakagami. 1966. Gigantism and dwarfism in bee eggs in relation to the mode of life, with notes on the number of ovarioles. Japanese Journal of Ecology 16: 4-16.

Rozen, J.G., Jr. 1991. Evolution of cleptoparasitism in anthophorid bees as revealed by their mode of parasitism and first instars (Hymenoptera: Apoidea). American Museum Novitates 3029: $1-36$.

Rozen, J.G., Jr. 2003. Eggs, ovariole numbers, and modes of parasitism of cleptoparasitic bees, with emphasis on Neotropical species (Hymenoptera: Apoidea). American Museum Novitates 3413: 1-36.

Rozen, J.G., Jr., and S.M. Kamel. 2006. Interspecific variation in immature larvae of the cleptoparasitic bee genus Coelioxys (Hymenoptera: Megachilidae). Journal of the Kansas Entomological Society 79: 348358.

Rozen, J.G., Jr., and S.M. Kamel. 2007. Investigations on the biologies and immature stages of the cleptoparasitic bee genera Radoszkowskiana and Coelioxys and their Megachile hosts (Hymenoptera: Apoidea: Megachilidae: Megachilini). American Museum Novitates 3573: $1-43$.

Rozen, J.G., Jr., and S.M. Kamel. 2008. Hospicidal behavior of the cleptoparasitic bee Coelioxys (Allocoelioxys) coturnix, including descriptions of its early larval instars (Hymenoptera: Megachilidae). 
Rozen, J.G., Jr., and H. Özbek. 2004. Immature stages of the cleptoparasitic bee Dioxys cincta (Apoidea: Megachilidae: Megachilinae: Dioxyini). American Museum Novitates 3443: $1-12$.

Rozen, J.G., Jr., and H. Özbek. 2005. Egg deposition of the cleptoparasitic bee Dioxys cincta (Hymenoptera: Apoidea: Megachilidae). Journal of the Kansas Entomological Society 78: $34-40$.

Vinson, S.B., G.W. Frankie, and R.E. Coville. 1987. Nesting habits of Centris flavofasciata Friese (Hymenoptera: Apoidea: Anthophori- dae) in Costa Rica. Journal of the Kansas Entomological Society 60: 249-263.

Vinson, S.B., G.W. Frankie, and H.J. Williams. 2006. Nest liquid resources of several cavity nesting bees in the genus Centris and the identification of a preservative, levulinic acid. Journal of Chemical Ecology 32: 2013-2021.

Vinson, S.B., A. Rao, and G. Frankie. In press. The field behavior of Coelioxys chichimeca (Hymenoptera: Megachilidae), a parasitic bee of the nests of the solitary bee, Centris bicornuta (Hymenoptera: Apidae) and the female host bee's response. Apidology. 